\title{
Chemical Components and Biological Effects of Genus Origanum
}

\author{
Li Zhou $\mathbb{D}^{1},{ }^{1}$ Fatma Al-Zahra Kamal Kamel Attia $\left(\mathbb{D},{ }^{1,2,3}\right.$ Lijun Meng $\mathbb{D}^{1},{ }^{1}$ Sitan Chen $\left(\mathbb{D},{ }^{1}\right.$ \\ Zhenhua Liu $\mathbb{D},{ }^{1,2,4}$ Changyang Ma $\mathbb{D}^{1,2,4}$ Lijun Liu $\mathbb{D}^{1,5}$ and Wenyi Kang $\mathbb{D}^{1,2}$ \\ ${ }^{1}$ National R\&D Center for Edible Fungus Processing Technology, Henan University, Kaifeng 475004, China \\ ${ }^{2}$ Joint International Research Laboratory of Food \& Medicine Resource Function, Henan, Kaifeng 475004, China \\ ${ }^{3}$ Department of Ornamental Medicinal and Aromatic Plants, Faculty of Agriculture, Assiut University, Asyut 71515, Egypt \\ ${ }^{4}$ Kaifeng Key Laboratory of Functional Components in Health Food, Kaifeng 475004, China \\ ${ }^{5}$ Huaihe Hospital, Henan University, Kaifeng 475004, China
}

Correspondence should be addressed to Zhenhua Liu; liuzhenhua623@163.com, Changyang Ma; macaya1024@vip.henu.edu.cn, Lijun Liu; funiuxzr2001@163.com, and Wenyi Kang; kangweny@hotmail.com

Received 6 May 2021; Revised 18 August 2021; Accepted 20 August 2021; Published 6 September 2021

Academic Editor: Quancai Sun

Copyright (C) 2021 Li Zhou et al. This is an open access article distributed under the Creative Commons Attribution License, which permits unrestricted use, distribution, and reproduction in any medium, provided the original work is properly cited.

The plants from genus Origanum are common folk Chinese herbs used to treat a variety of diseases. They are also used as a spice, a seasoning, and an ornament. Origanum plants are rich in essential oils and also have other compounds including terpenoids, flavonoids, organic acids, and sterols. They have a variety of biological activities such as antispasmodic, anti-inflammatory, growth-promoting, antibacterial, antioxidant, and anticancer properties. The chemical components and biological effects of genus Origanum were summarized by different scientific databases such as Web of Science, SciFinder, Baidu Scholar, PubMed, ScienceDirect, and SpringerLink. In conclusion, recent studies were mainly focused on the activities of their essential oils. The research studies for nonvolatile constituents and their pharmacological activities are few. Therefore, research on compounds in genus Origanum plants can be strengthened and their application prospect can be explored so as to make better use of the resources of these plants.

\section{Introduction}

The genus Origanum (Lamiaceae) is an annual, perennial, and shrubby herb. It comprises about 15 to 20 species and is widely distributed throughout the world. There is only one species of genus Origanum (O. vulgare) in China, mainly distributed in Xinjiang, Gansu, Shanxi, Hubei, and Henan Provinces, etc. [1].

The whole plants of the genus Origanum can be used medicinally throughout the world. For example, O. majorana has been used in ancient Egypt as antiseptic, insect repellent, and expectorant and for arthritis, muscle pain, rheumatism, and other diseases and is now widely used in cooking seasonings and cosmetics. O. vulgare subsp. glandulosum (syn. O. glandulosum) is named 'Zaâter moulouk' in Tunisia. It is one of the most important plants of Lamiaceae economically, and several studies have shown that genus Origanum possessed the antimicrobial, antifungal, and insecticidal properties and antioxidant activities. In China, the whole plant of O. vulgare is a common Chinese herbal medicine in Chinese folk and was listed in Chinese Pharmacopoeia (1977 edition). It has the function of clearing away heat and reducing swelling and mainly used for sunstroke, cold, headache, acute enteritis, abdominal pain, and diarrhea. It is also used as a spice, condiment, and ornament.

Researches on genus Origanum are mainly carried out in Egypt, Tunisia, Turkey, and so on. The chemical constituents of genus Origanum are mainly essential oils, with the effects of removing phlegm, resisting spasm, nourishing and strengthening body, relieving pain, and having antisepsis, antibacterial, antimildew, antioxidation, and anticytotoxin effects. The nonvolatile constituents of Origanum plants are seldom studied, which mainly contain flavonoids, triterpenes, and organic acids. Therefore, systematic studies of their chemical constituents and biological activities are of great significance to elucidate its medicinal value. 


\section{Chemical Constituents}

The essential oils of genus Origanum contain many active constituents. They have a broad spectrum of antibacterial, antitumor, and immunomodulatory effects, but there are few studies on the nonvolatile constituents, including flavonoids, organic acids, terpenoids, and sterols. The main constituents of essential oils from genus Origanum in the world are listed in Table 1 and the nonvolatile constituents of genus Origanum in the world are listed in Table 2.

\subsection{Main Constituents of Essential Oils of Genus Origanum.} Plants of genus Origanum are rich in essential oils and the main constituents are terpenoids, which mainly include carvacrol, thymol, carbamene, and terpilenol (Figures 1-3). [2-8, 18-20].

Hatipi collected 12 plants of $O$. vulgare from different parts in Kosovo. The essential oils were extracted by steam distillation and the yield of essential oils was $0.41-0.82 \%$ of dry weight. The main constituents included sesquiterpenoids (6.1-37.06\%), monoterpenes (1.73-35.18\%), oxygenated monoterpene $(6.88-36.06 \%)$, oxygenated sesquiterpenoids (2.49-43.44\%), 1, 8-cineole (1.31-13.54\%), caryophyllene oxide $(0.18-38.05 \%),(E)$ - $\beta$-caryophyllene $(0.48-14.0 \%), p$ cymene (1.27-19.62\%), $\alpha$-terpineol (1.05-19.23\%), and germacrene D (0.35-16.09\%) [19].

The essential oils from the above ground parts of O. heracleoticum and O. majorana made up $1.8 \%$ and $0.4 \%$ of their total dry weight, respectively. 55 compounds were identified from the essential oils, among which 35 compounds were from $O$. heracleoticum, accounting for $97.8 \%$ of the total oils, and 20 compounds were from O. majorana, accounting for $98.0 \%$ of the total oils. Oxygenated monoterpenes $(80.1 \%)$ were the main constituents of $O$. heracleoticum essential oils, while monoterpenes (54.0\%) were mainly found in O. majorana essential oils. Carvacrol (77.8\%), p-cymene (5.3\%), $\gamma$-terpinene $(4.9 \%)$, and caryophyllene $(1.3 \%)$ were the main components in $O$. heracleoticum essential oils. In O. majorana essential oils, the main constituents included terpineol (29.6\%), 2carene $(20.1 \%)$, camphene $(13.4 \%)$, and $\alpha$-pinene $(7.9 \%)$ [8].

Huo found monoterpenes and bicyclic sesquiterpenes were the main constituents of the essential oils of $O$. vulgare L. through the analysis of GC-MS, and the mass fractions of these two kinds of components in the essential oils of O. vulgare L. were $69.31 \%$ and $20.25 \%$, respectively [20].

Gong identified 65 chemical constituents from the essential oils of genus Origanum plants in 6 different habitats from China and Pakistan by GC-MS and found that the main constituents of essential oils in 6 different habitats were all oxygenated monoterpenes [2].

Essential oils of $O$. onites aerial parts were analyzed by GC-MS with hydrodistillation (HD) and microwave-assisted HD (MWHD) methods. Thirty-one compounds were identified from HD method and 52 compounds were identified from MWHD method. Among them, carvacrol (76.8\% HD and 79.2\% MWHD) and thymol (4.7\% HD and
4.4\% MWHD) were the main constituents of these two essential oils [4]. Farhat found essential oils from the leaves of O. syriacum in Syria were mainly carvacrol (78.4\%) and thymol (17.9\%) analyzed by SPME GC/MS [7].

Shafaghat obtained 23 compounds from the essential oils of flowers, leaves, and stems of $O$. vulgare growing in northwest Iran by GC-MS, about $96.3 \%$ (19 compounds) of the flower oil, $92.8 \%$ (11 compounds) of the leaf oil, and 95.2\% (12 compounds) of the stem oil. The dominant compounds in the flower, leaf, and stem oils were sesquiterpene $(53.6 \%, 50.7 \%$, and $70.4 \%$, respectively) and linalyl acetate, sabinene, $\gamma$-terpinene and ocimene were the main constituents of the oil of the aerial parts of $O$. vulgare [6].

Aligiannis identified 48 compounds from the essential oils of $O$. scabrum and O. microphyllum, accounting for $98.59 \%$ and $98.66 \%$ of the total oils, respectively. Carvacrol, terpilenol, linalool, sabinene, and terpinene are the main constituents [5].

Spyridopoulou identified 64 compounds from essential oils of $O$. onites. The most abundant chemical constituent in essential oils is carvacrol (47.99\%), which is consistent with those reported in literatures that the content of carvacrol in essential oils was between $50 \%$ and $85 \%$. Other main constituents were identified as terp-1-in-4-ol (6.79\%), sabinene hydrate $(6.14 \%), \gamma$-terpinene $(5.20 \%), p$-cymene $(3.85 \%)$, and $\alpha$-terpineol (3.76\%) [3].

In conclusion, 92 compounds were found in essential oils to date, including monoterpenes (1-49), sesquiterpenoids (50-69), and other derivatives (70-92). Moreover, the chemical constituents of essential oils varied greatly with species in the genus Origanum and can be roughly divided into two categories: one is rich in carvacrol, thymol, cymene, and terpinene and the other is rich in coriandrol, germacrene $\mathrm{D}$, and other ingredients. When the chemical constituents of essential oils in a certain plant were rich in the first group, then the compounds of the second group were few, and vice versa. Meanwhile, essential oils have many pharmacological activities. Therefore, understanding of their chemical compositions of essential oils thoroughly is more helpful to elucidate their material basis.

\subsection{Nonessential Constituents of Genus Origanum}

2.2.1. Flavonoids. 23 flavonoids (93-115) (Figure 4) were isolated from genus Origanum [9-14]. Compounds 93-107 belong to flavonoids, 108-111 belong to flavonols, and 112-115 belong to flavanone and their glycosides.

2.2.2. Organic Acids. 20 organic acid compounds (116-135) (Figure 5) were isolated from genus Origanum [9-16], mainly including phenols, cinnamic acids, and salvianolic acids.

2.2.3. Terpenes and Sterols. The terpenoids oleanolic acid (136), arbutin (137) [13], sterol stigmasterol (138) [11], $\beta$-sitosterol (139), and daucosterol (140) were isolated from genus Origanum (Figure 6) [15]. 
TABLe 1: The main constituents of essential oils from genus Origanum in the world.

\begin{tabular}{|c|c|c|c|c|c|}
\hline Compound & Name & Source & Parts & Producing area & References \\
\hline \multicolumn{6}{|c|}{ Monoterpenes (1-51) } \\
\hline 1 & Myrcene & O. vulgare & The whole plants & Anhui, China & {$[2]$} \\
\hline 2 & Nerol & O. onites & Leaves, flowers & Athens, Greece & [3] \\
\hline 3 & Geraniol & O. vulgare & The whole plants & Xinjiang, China & {$[2]$} \\
\hline 4 & $\beta$-Citronellal & O. onites & Aerial parts & Izmir, Turkey & {$[4]$} \\
\hline 5 & Acetic acid, geraniol ester & O. vulgare & The whole plants & Kunlun Mountain & {$[2]$} \\
\hline 6 & Citronellol acetate & O. vulgare & The whole plants & Kunlun Mountain & {$[2]$} \\
\hline 7 & Ocimene & O. microphyllum & Aerial parts & Crete & {$[5]$} \\
\hline 8 & Citral & O. onites & Leaves, flowers & Athens, Greece & {$[3]$} \\
\hline 9 & Citronellol & O. vulgare & The whole plants & Henan, China & {$[2]$} \\
\hline 10 & Citronellyl formate & O. vulgare & The whole plants & Pakistan & {$[2]$} \\
\hline 11 & Hydroxycitronellal & O. vulgare SSP. & $\begin{array}{c}\text { Flowers, leaves, } \\
\text { stems }\end{array}$ & Astara, Iran & {$[6]$} \\
\hline 12 & Neryl acetate & O. onites & Leaves, flowers & Athens, Greece & {$[3]$} \\
\hline 13 & Linalool & O. microphyllum & Aerial parts & Crete & {$[5]$} \\
\hline 14 & Linalyl acetate & O. onites. & Leaves, flowers & Athens, Greece & [3] \\
\hline 15 & Epoxy linalool & O. onites & Leaves, flowers & Athens, Greece & [3] \\
\hline 16 & $\alpha$-Terpinene & O. microphyllum & Aerial parts & Crete & {$[5]$} \\
\hline 17 & $\gamma$-Terpinene & O. syriacum & Leaves & $\begin{array}{l}\text { Arabsalim, } \\
\text { Lebanon }\end{array}$ & [7] \\
\hline 18 & $\alpha$-Phellandrene & O. onites & Leaves, flowers & Athens, Greece & {$[3]$} \\
\hline 19 & Terpinolene & O. microphyllum & Aerial parts & Crete & {$[5]$} \\
\hline 20 & $\beta$-Phellandrene & O. scabrum & Aerial parts & Peloponissos & {$[5]$} \\
\hline 21 & Limonene & O. heracleoticum & Dried aerial parts & $\begin{array}{c}\text { Salerno, } \\
\text { Montecorice }\end{array}$ & {$[8]$} \\
\hline 22 & Cymene & O. vulgare SSP. & $\begin{array}{c}\text { Flowers, leaves, } \\
\text { stems }\end{array}$ & Astara, Iran & {$[6]$} \\
\hline 23 & Piperitol & O. onites & Leaves, flowers & Athens, Greece & {$[3]$} \\
\hline 24 & Thymol & O. scabrum & Aerial parts & Peloponissos & {$[5]$} \\
\hline 25 & p-Cymen-2-ol & O. vulgare & The whole plants & Pakistan & {$[2]$} \\
\hline 26 & Terpinen-4-ol & O. scabrum & Aerial parts & Peloponissos & {$[5]$} \\
\hline 27 & $\alpha$-Terpineol & O. microphyllum & Aerial parts & Crete & {$[5]$} \\
\hline 28 & p-Cymen-8-ol & O. onites & Aerial parts & Izmir, Turkey & {$[4]$} \\
\hline 29 & trans-Dihydrocarvone & O. heracleoticum & Aerial parts & $\begin{array}{c}\text { Salerno, } \\
\text { Montecorice }\end{array}$ & {$[8]$} \\
\hline 30 & Carvone & O. onites & Aerial parts & Izmir, Turkey & {$[4]$} \\
\hline 31 & Isopiperitenone & O. onites & Leaves, flowers & Athens, Greece & {$[3]$} \\
\hline 32 & Thymol methyl ether & O. heracleoticum & Dried aerial parts & $\begin{array}{c}\text { Salerno, } \\
\text { Montecorice }\end{array}$ & {$[8]$} \\
\hline 33 & Carvacrol methyl ether & O. onites & Leaves, flowers & Athens, Greece & {$[3]$} \\
\hline 34 & Benzene, 1-methoxy-4-methyl-2-(1-methylethyl) & O. vulgare & The whole plants & Pakistan & {$[2]$} \\
\hline 35 & Thymol acetate & O. vulgare & The whole plants & Anhui, China & {$[2]$} \\
\hline 36 & Carvacrol acetate & O. vulgare & The whole plants & Anhui, China & {$[2]$} \\
\hline 37 & $\alpha$-Campholenal & O. vulgare SSP. & $\begin{array}{c}\text { Flowers, leaves, } \\
\text { stems }\end{array}$ & Astara, Iran & {$[6]$} \\
\hline 38 & Sabinene & O. microphyllum & Aerial parts & Crete & {$[5]$} \\
\hline 39 & Thujene & O. heracleoticum & Dried aerial parts & $\begin{array}{c}\text { Salerno, } \\
\text { Montecorice }\end{array}$ & {$[8]$} \\
\hline 40 & Thujanol & O. onites & Leaves, flowers & Athens, Greece & {$[3]$} \\
\hline 41 & Thujone & O. onites & Aerial parts & Izmir, Turkey & {$[4]$} \\
\hline 42 & Sabinene hydrate & O. scabrum & Aerial parts & Peloponissos & {$[5]$} \\
\hline 43 & $\alpha$-3-Carene & O. scabrum & Aerial parts & Peloponissos & {$[5]$} \\
\hline 44 & Pinocarvone & O. vulgare SSP. & $\begin{array}{c}\text { Flowers, leaves, } \\
\text { stems }\end{array}$ & Astara, Iran & {$[6]$} \\
\hline 45 & $\alpha$-Pinene & O. vulgare SSP. & $\begin{array}{c}\text { Flowers, leaves, } \\
\text { stems }\end{array}$ & Astara, Iran & {$[6]$} \\
\hline 46 & $\beta$-Pinene & O. scabrum & Aerial parts & Peloponissos & {$[5]$} \\
\hline 47 & $\alpha$-trans-bergamotene & O. vulgare & The whole plants & Anhui, China & {$[2]$} \\
\hline 48 & Camphene & O. microphyllum & Aerial parts & Crete & {$[5]$} \\
\hline
\end{tabular}


TABle 1: Continued.

\begin{tabular}{|c|c|c|c|c|c|}
\hline Compound & Name & Source & Parts & Producing area & References \\
\hline 49 & Borneol & O. vulgare SSP. & $\begin{array}{l}\text { Flowers, leaves, } \\
\text { stems }\end{array}$ & Astara, Iran & {$[6]$} \\
\hline 50 & (Z)- $\beta$-Farnesene & O. vulgare & The whole plants & Anhui, China & {$[2]$} \\
\hline 51 & $(\mathrm{E}, \mathrm{E})$ - $\alpha$-Farnesene & O. vulgare & The whole plants & Xinjiang, China & {$[2]$} \\
\hline \multicolumn{6}{|c|}{ Sesquiterpenoids (52-69) } \\
\hline 52 & Germacrene D & O. onites & Leaves, flowers & Athens, Greece & {$[3]$} \\
\hline 53 & $\beta$-Sesquiphellandrene & O. vulgare & Leaves, flowers & Athens, Greece & {$[3]$} \\
\hline 54 & $\beta$-Bisabolene & O. onites & Aerial parts & Izmir, Turkey & {$[4]$} \\
\hline 55 & $\beta$-Bisabolene & O. scabrum & Aerial parts & Peloponissos & {$[5]$} \\
\hline 56 & Germacrene B & O. vulgare & The whole plants & Xinjiang, China & {$[2]$} \\
\hline 57 & Humulene & O. microphyllum & Aerial parts & Crete & {$[5]$} \\
\hline 58 & $\gamma$-Muurolene & O. vulgare & The whole plants & Henan, China & {$[2]$} \\
\hline 59 & $\gamma$-Cadinene & O. onites & Leaves, flowers & Athens, Greece & [3] \\
\hline 60 & Cubenol & O. vulgare & The whole plants & Xinjiang, China & {$[2]$} \\
\hline 61 & Cadinol & O. onites & Leaves, flowers & Athens, Greece & [3] \\
\hline 62 & Limonene & O. heracleoticum & Dried aerial parts & $\begin{array}{l}\text { Salerno, } \\
\text { Montecorice }\end{array}$ & {$[8]$} \\
\hline 63 & $\alpha$-Bulnesene & O. vulgare & The whole plants & Anhui, China & {$[2]$} \\
\hline 64 & Caryophyllene & O. heracleoticum & Dried aerial parts & $\begin{array}{l}\text { Salerno, } \\
\text { Montecorice }\end{array}$ & {$[8]$} \\
\hline 65 & Caryophyllene oxide & O. scabrum & Aerial parts & Peloponissos & {$[5]$} \\
\hline 66 & Spathulenol & O. vulgare SSP. & $\begin{array}{l}\text { Flowers, leaves, } \\
\text { stems }\end{array}$ & Astara, Iran & {$[6]$} \\
\hline 67 & Aromadendrene & O. onites & Leaves, flowers & Athens, Greece & {$[3]$} \\
\hline 68 & Thujopsene & O. vulgare SSP. & $\begin{array}{l}\text { Flowers, leaves, } \\
\text { stems }\end{array}$ & Astara, Iran & {$[6]$} \\
\hline 69 & Copaene & O. vulgare & The whole plants & Henan, China & {$[2]$} \\
\hline \multicolumn{6}{|c|}{ Others (70-92) } \\
\hline 70 & Octen-3-ol & O. scabrum & Aerial parts & Peloponissos & [5] \\
\hline 71 & 3-Octanone & O. scabrum & Aerial parts & Peloponissos & [5] \\
\hline 72 & 3-Octanol & O. vulgare & The whole plants & Henan, China & {$[2]$} \\
\hline 73 & Methyl 2-methylbutyrate & O. onites & Leaves, flowers & Athens, Greece & [3] \\
\hline 74 & Isoamyl acetate & O. onites & Leaves, flowers & Athens, Greece & [3] \\
\hline 75 & Cis-rose oxide & O. vulgare & The whole plants & Xinjiang, China & {$[2]$} \\
\hline 76 & Phenylacetaldehyde & O. microphyllum & Aerial parts & Crete & [5] \\
\hline 77 & Eugenol & O. heracleoticum & Dried aerial parts & $\begin{array}{l}\text { Salerno, } \\
\text { Montecorice }\end{array}$ & {$[8]$} \\
\hline 78 & Camphor & O. onites & \multirow{2}{*}{$\begin{array}{c}\text { Leaves, flowers } \\
\text { Flowers, leaves, } \\
\text { stems }\end{array}$} & Athens, Greece & [3] \\
\hline 79 & p-Methylbenzaldehyde & O. vulgare SSP. & & Astara, Iran & {$[6]$} \\
\hline 80 & Acetovanillone & O. heracleoticum & Dried aerial parts & $\begin{array}{l}\text { Salerno, } \\
\text { Montecorice }\end{array}$ & {$[8]$} \\
\hline 81 & Eugenol methyl ether & O. vulgare & The whole plants & Anhui, China & {$[2]$} \\
\hline 82 & Isoeugenol methyl ether & O. vulgare & The whole plants & Anhui, China & {$[2]$} \\
\hline 83 & Elemicin & O. vulgare & The whole plants & Anhui, China & {$[2]$} \\
\hline 84 & Myristicin & O. vulgare & The whole plants & Anhui, China & {$[2]$} \\
\hline 85 & Apiol & O. vulgare & The whole plants & Anhui, China & {$[2]$} \\
\hline 86 & Dill apiol & O. vulgare & The whole plants & Anhui, China & {$[2]$} \\
\hline 87 & Cis-asarone & O. vulgare & The whole plants & Anhui, China & {$[2]$} \\
\hline 88 & Asarone & O. vulgare & \multirow{2}{*}{$\begin{array}{c}\text { The whole plants } \\
\text { Flowers, leaves, } \\
\text { stems }\end{array}$} & Anhui, China & {$[2]$} \\
\hline 89 & 5-Methylfurfural & O. vulgare SSP. & & Astara, Iran & {$[6]$} \\
\hline 90 & $\begin{array}{c}\text { 1, 5, 5, 8-Tetramethyl-12-oxabicyclo [9.1.0] dodeca- } \\
\text { 3, 7-diene }\end{array}$ & O. vulgare & The whole plants & Xinjiang, China & {$[2]$} \\
\hline 91 & Indole & O. onites & \multirow{2}{*}{$\begin{array}{c}\text { Leaves, flowers } \\
\text { Flowers, leaves, } \\
\text { stems }\end{array}$} & Athens, Greece & [3] \\
\hline 92 & 5-Phenylisoquinoline & O. vulgare SSP. & & Astara, Iran & {$[6]$} \\
\hline
\end{tabular}


TABLe 2: Nonvolatile constituents of genus Origanum in the world.

\begin{tabular}{|c|c|c|c|c|c|}
\hline Compound & Name & Source & Parts & Producing area & References \\
\hline \multicolumn{6}{|c|}{ Flavonoids (93-115) } \\
\hline 93 & Luteolin & O. vulgare & Dried aerial parts & Taiwan, China & [9] \\
\hline 94 & Apigenin & O. vulgare & Dried aerial parts & Taiwan, China & [9] \\
\hline 95 & Luteolin7-O- $\beta$-D-glucopyranoside & O. vulgare & Dried aerial parts & Taiwan, China & [9] \\
\hline 96 & Luteolin7-O- $\beta$-D-glucuronide & O. vulgare & Dried aerial parts & Taiwan, China & [9] \\
\hline 97 & Luteolin7-O- $\beta$-D-xylopyranoside & O. vulgare & Dried aerial parts & Taiwan, China & [9] \\
\hline 98 & Apigenin7-O- $\beta$-D-glucuronide & O. vulgare & Dried aerial parts & Taiwan, China & [9] \\
\hline 99 & Apigenin7-O- $\beta$-D- $\left(6^{\prime \prime}\right.$-methyl) glucuronide & O. vulgare & Dried aerial parts & Taiwan, China & [9] \\
\hline 100 & $5,6,3^{\prime}$-Trihydroxy-7, $8,4^{\prime}$-trimethoxyflavone & O. majorana & Dried aerial parts & Tokat, Turkey & {$[10]$} \\
\hline 101 & $5,6,4^{\prime}$-Trihydroxyl-7, 8-dimethoxylflavone & O. $x$ intercedens & - & Greece & {$[11]$} \\
\hline 102 & $5,6,4^{\prime}$-Trihydroxyl-7, $3^{\prime}$-dimethoxylflavone & O. $x$ intercedens & - & Greece & {$[11]$} \\
\hline 103 & $5,6,4^{\prime}$-Trihydroxyl-7, $8,3^{\prime}$-trimethoxylflavone & O. $x$ intercedens & - & Greece & {$[11]$} \\
\hline 104 & $6,7,4^{\prime}$-Trihydroxyflavone & O. vulgare & The whole plants & Guangdong, China & {$[12]$} \\
\hline 105 & Tilianin & O. vulgare & The whole plants & - & [13] \\
\hline 106 & 5, 4'-Dihydroxyl-6, 7-dimethoxylflavone & O. $x$ intercedens & - & Greece & {$[11]$} \\
\hline 107 & 5, 4'-Dihydroxyl-6, 7-dimethoxylflavone & O. $x$ intercedens & - & Greece & {$[11]$} \\
\hline 108 & Kaempferol & O. vulgare & - & - & {$[14]$} \\
\hline 109 & Quercetin & O. vulgare & - & - & {$[14]$} \\
\hline 110 & Morin & O. vulgare. & - & - & {$[14]$} \\
\hline 111 & Galangin & O. vulgare & - & - & {$[14]$} \\
\hline 112 & Naringin & O. vulgare & - & - & {$[14]$} \\
\hline 113 & Hesperetin & O. vulgare & Dried aerial parts & - & {$[10]$} \\
\hline 114 & Didymin & O. vulgare & The whole plants & Guangdong, China & {$[12]$} \\
\hline 115 & Sagittatoside A & O. vulgare & The whole plants & - & [13] \\
\hline \multicolumn{6}{|c|}{ Organic acids (116-135) } \\
\hline 116 & p-Dihydroxybenzene & O. majorana & Dried aerial parts & Tokat, Turkey & {$[10]$} \\
\hline 117 & O-Dihydroxybenzene & O. vulgare & Dried aerial parts & Hubei, China & {$[15]$} \\
\hline 118 & 1, 2, 4-Trihydroxyphenol & O. vulgare & The whole plants & Guangdong, China & {$[12]$} \\
\hline 119 & 4-Methyl-5-isopropyl catechol & O. vulgare & Dried aerial parts & Hubei, China & {$[15]$} \\
\hline 120 & Cinnamic acid & O. vulgare & - & - & {$[14]$} \\
\hline 121 & 2-Hydroxycinnamic acid & O. vulgare & - & Greece & {$[11]$} \\
\hline 122 & 4-Hydroxycinnamic acid & O. dictamnus & - & Greece & {$[11]$} \\
\hline 123 & Caffeic acid & O. vulgare & - & - & {$[14]$} \\
\hline 124 & Ferulic acid & O. dictamnus & - & Greece & [11] \\
\hline 125 & Chlorogenic acid & O. vulgare & - & - & {$[14]$} \\
\hline 126 & Rosmarinic acid & O. vulgare & The whole plants & Hubei, China & {$[16]$} \\
\hline 127 & p-Hydroxybenzoic acid & O. vulgare & - & - & {$[14]$} \\
\hline 128 & Protocatechuic acid & O. vulgare & The whole plants & Hubei, China & {$[16]$} \\
\hline 129 & Hydroxy-3-methoxybenzoic acid & O. vulgare & The whole plants & Hubei, China & {$[16]$} \\
\hline 130 & Hydroxy-4-methoxybenzoic acid & O. vulgare & The whole plants & Hubei, China & {$[16]$} \\
\hline 131 & Syringic acid & O. vulgare & -1 & - & {$[14]$} \\
\hline 132 & Salvianolic acid A & O. vulgare & Dried aerial parts & Taiwan, China & {$[10]$} \\
\hline 133 & Salvianolic acid C & O. vulgare & Dried aerial parts & Taiwan, China & {$[10]$} \\
\hline 134 & Lithospermic acid & O. vulgare & Dried aerial parts & Taiwan, China & {$[10]$} \\
\hline 135 & Succinic acid & O. vulgare & Dried aerial parts & Hubei, China & {$[15]$} \\
\hline \multicolumn{6}{|c|}{ Steroids and terpenes (136-140) } \\
\hline 136 & Oleanolic acid & O. vulgare & The whole plants & - & {$[13]$} \\
\hline 137 & Arbutin & O. vulgare & The whole plants & - & [13] \\
\hline 138 & Stigmasterol & O. minutiflorum & - & - & {$[11]$} \\
\hline 139 & $\beta$-Sitosterol & O. vulgare & Dried aerial parts & Hubei, China & {$[15]$} \\
\hline 140 & Daucosterol & O. vulgare & Dried aerial parts & Hubei, China & {$[15]$} \\
\hline \multicolumn{6}{|c|}{ Others (141-148) } \\
\hline 141 & Origalignanol & O. vulgare & Dried aerial parts & Taiwan, China & [9] \\
\hline 142 & Origanol A & O. vulgare & The air-dried leaves & Ooty, India & {$[17]$} \\
\hline 143 & Origanol B & O. vulgare & The air-dried leaves & Ooty, India & {$[17]$} \\
\hline 144 & Ethyl rosmarinate & O. vulgare & Dried aerial parts & Hubei, China & {$[15]$} \\
\hline 145 & N-Butyl rosmarinate & O. vulgare & Dried aerial parts & Hubei, China & {$[15]$} \\
\hline 146 & p-Hydroxy benzaldehyde & O. vulgare & Dried aerial parts & Hubei, China & [15] \\
\hline 147 & Dihydrodehydrodiconiferyl alcohol & O. vulgare & Dried aerial parts & Hubei, China & {$[15]$} \\
\hline 148 & Caffeic acid ethyl ester & O. vulgare & Dried aerial parts & Hubei, China & [15] \\
\hline
\end{tabular}




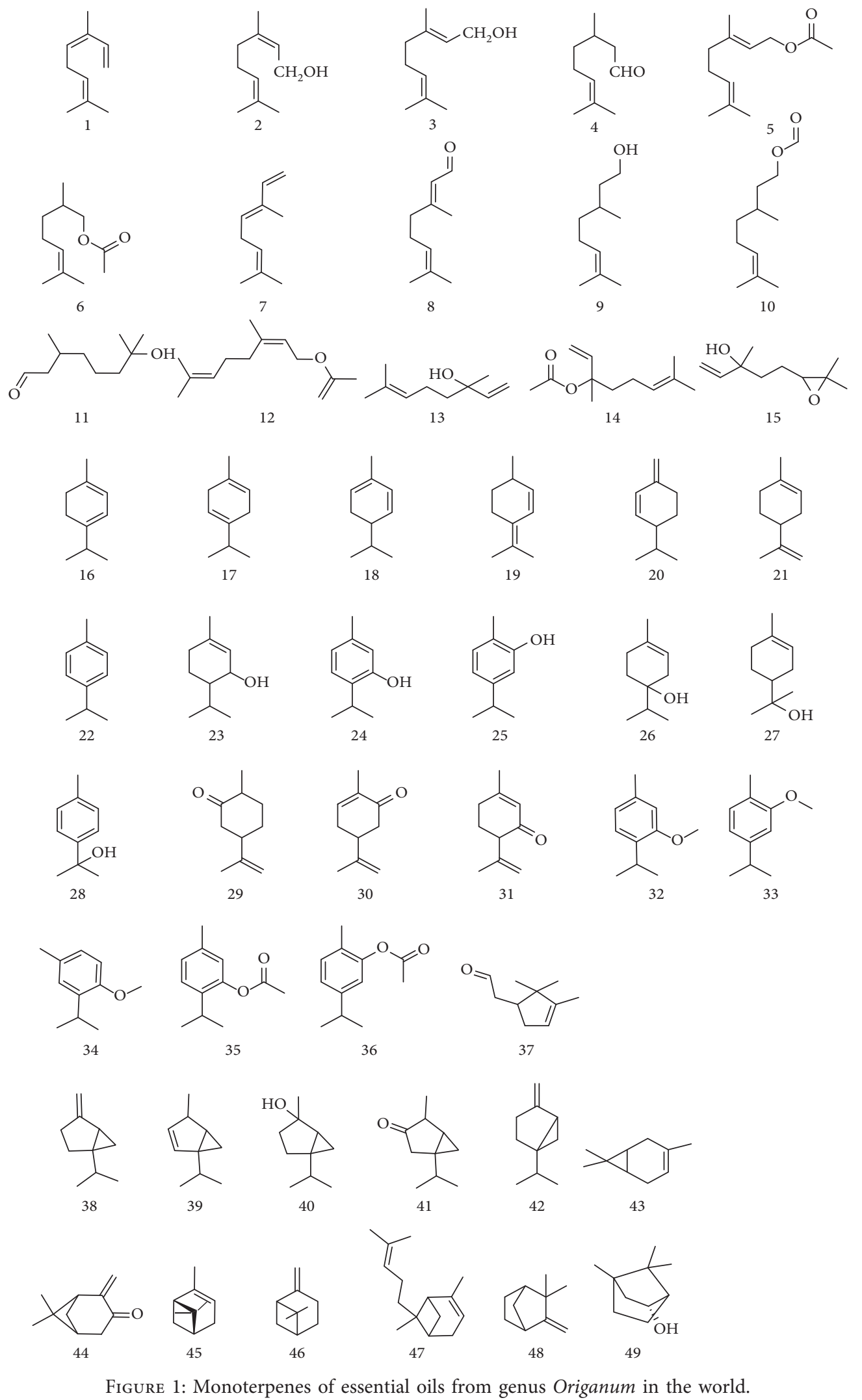




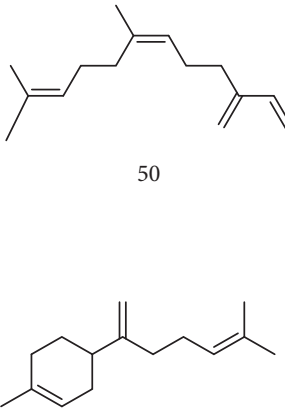

55

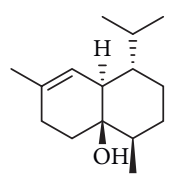

60

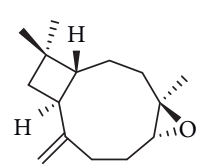

65

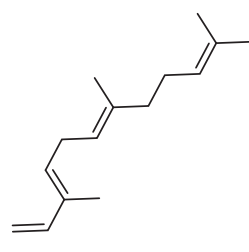

51

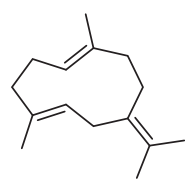

56

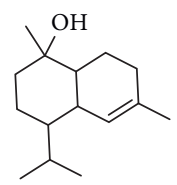

61

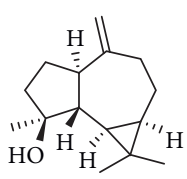

66

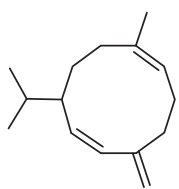

52
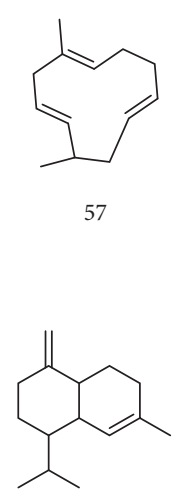

62

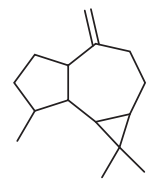

67

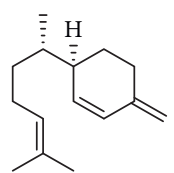

53<smiles>C=C1CC[C@H](C(C)C)[C@H]2C=C(C)CC[C@H]12</smiles>

58

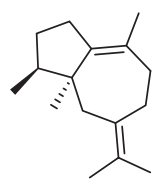

63

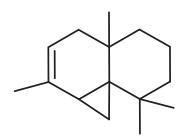

68

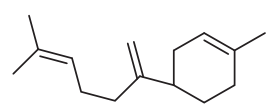

54

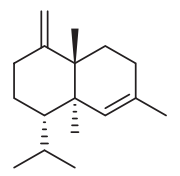

59

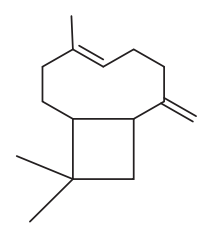

64

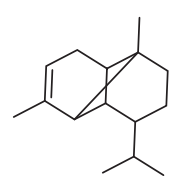

69

Figure 2: Sesquiterpenoids of essential oils isolated from genus Origanum in the world.

2.2.4. Others. Origalignanol was isolated from $O$. vulgare by Lin (141) [9]. Origanol A (142) and origanol B (143) were isolated from $O$. vulgare by Gottumukkala [17]. Sun isolated ethyl rosmarinate (144), $N$-butyl rosmarinate (145), $p$-hydroxybenzaldehyde (146), dihydrodehydrodiconiferyl alcohol (147), and caffeic acid ethyl ester (148) from O. vulgare L. (Figure 7) [15].

\section{Biological Effects}

The researches on the biological effects of genus Origanum are mainly focused on its essential oils, which have a wide range of biological effects, including antibacterial, antioxidant, anticancer, and anti-inflammatory effects and immune regulation.

3.1. Antibacterial Effect. Essential oils from genus Origanum had a strong antibacterial and bactericidal effect, which is related to its phenols' constituents. Phenols act on the cell membrane of bacteria to make their proteins denaturation and change the permeability of cell membrane, or destroy protein synthesis by reacting with phospholipids in cell membranes and finally inhibiting the growth of microbial cells [21, 22].

The antibacterial activities of $O$. dictamnus essential oils against Salmonella enteritis, S. typhimurium, Escherichia coli, Listeria monocytogenes, Staphylococcus epidermis, and
S. aureus were determined by disk diffusion method. The results showed that bacteriostatic effect on $S$. aureus was the strongest and on S. typhimurium was the weakest [23].

Laghmouchi determined the minimum inhibitory concentration (MIC: $0.06-0.25 \%(\mathrm{v} / \mathrm{v})$ ) and the minimum bactericidal concentration (MBC: $0.12-0.5 \%(\mathrm{v} / \mathrm{v})$ ) of essential oils from O. compactum against E. coli, B. subtilis, S. aureus, and L. innocua by the microdilution method. And thymol and carvacrol in essential oils played the key role in antibacterial activity through penetrating and depolarizing the plasma membrane. Meanwhile, $p$-cymene in essential oils could enhance the anti-S. aureus effect by promoting the transport of carvacrol in the plasma membrane and entering the lipid bilayer of Staphylococcus aureus [24].

The antibacterial activity of $O$. acutidens essential oils and its methanol extract against four fish pathogens, S. aureus, L. garvieae, Yersinia ruckeri, and Aeromonas hydrophila, were determined by disk diffusion assay. The results indicate that the methanol extract and the essential oils of $O$. acutidens may be valuable as potential antibacterial agents against the major fish pathogens [25].

Souza reported that essential oils from O. vulgare could block the production of enterotoxin of $S$. aureus. When the concentration reached 0.15 or $0.3 \mu \mathrm{L} / \mathrm{mL}$, the growth of bacteria was significantly inhibited. When the concentration reached 0.6 or $1.2 \mu \mathrm{L} / \mathrm{mL}$, the permeability of the cell membrane was changed and the cytoplasm was lost. These 


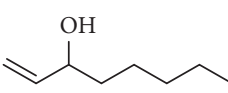

70<smiles>CC(C)=C[C@@H]1C[C@H](C)CCO1</smiles>

75<smiles>COc1cc(C(C)=O)ccc1O</smiles>

80

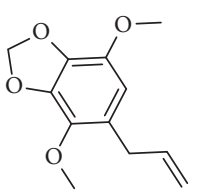

85

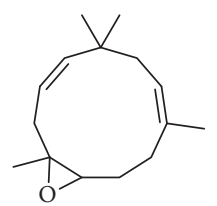

90

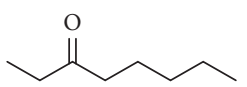

71

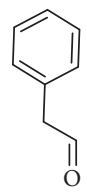

76

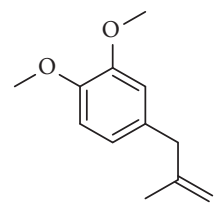

81

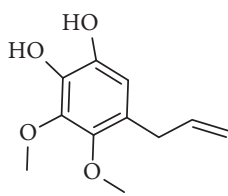

86

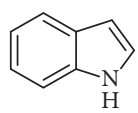

91

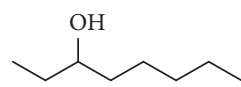

72<smiles>C/C=C/c1ccc(O)c(OC)c1</smiles>

77

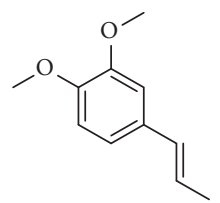<smiles>C/C=C/c1cc(OC)c(OC)cc1OC</smiles>

87<smiles>c1ccc(-c2cccc3cnccc23)cc1</smiles>

92<smiles>CCC(C)C(=O)OI</smiles>

73<smiles>CC(=O)C1C(C)(C)CC(=O)CC1(C)C</smiles>

78

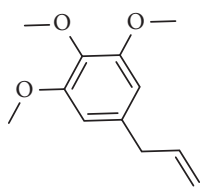

83<smiles>C/C=C/c1cc(OC)c(OC)cc1OC</smiles>

88<smiles>CC(=O)OCCC(C)C</smiles>

74<smiles>Cc1ccc(C=O)cc1</smiles>

79<smiles>C/C=C/Cc1cc(OC)c2c(c1)OCO2</smiles>

84

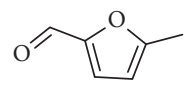

89

FIGURE 3: Other constituents of essential oils isolated from genus Origanum in the world.

suggested that essential oils from $O$. vulgare may prevent some of the symptoms caused by $S$. aureus enterotoxin [26].

Si studied the antibacterial effects of oregano essential oils (OEO) combined with antibiotics against extendedspectrum beta-lactamase (ESBL-) producing E. coli by twofold dilution method. The results indicated that multiple drug-resistant $E$. coli was very sensitive to OEO essential oils and polymycin. The antibacterial effects of OEO in combination with kanamycin were independent against $E$. coli. The antibacterial effects of OEO in combination with fluoroquinolones, doxycycline, lincomycin, and maquindox florfenicol displayed synergism against $E$. coli. The antibacterial effects of OEO combined with amoxicillin, polymycin, and lincomycin showed an additive effect against E. coli. Thus, in clinical application, the dosage of chemical antibiotics can be reduced to lessen the adverse reactions of antibiotics [27].

3.2. Antioxidant Effect. Genus Origanum oils had a strong antioxidant effect and could protect cells from oxidative stress. Anastasia proved that $O$. dubium extract had strong antioxidant activity, antilipid peroxidation, and inhibitory activity of lipoxygenase by measuring the interaction between $O$. dubium extractive and 1, 1-diphenylphenylhydrazine $(\mathrm{DPPH})$ radical [28].

Mechergui used the DPPH radical scavenging assay to determine the antioxidant activity of three essential oils of O. vulgare subsp. glandulosum (Desf.) from Tunisia. The results showed that the antioxidant activity of essential oils was mainly due to the presence of thymol and carvacrol and the presence of $p$-terpene. And antioxidant activity increased with the increase of total phenol content in essential oils [29].

O. majorana essential oils were found to be an effective antioxidant in vitro and exhibited concentration-dependent inhibitory effects on DPPH, hydroxyl radical, hydrogen peroxide, reducing power, and lipid peroxidation. The $\mathrm{IC}_{50}$ values were $58.67,67.11,91.25,78.67$, and $68.75 \mathrm{mg} / \mathrm{mL}$ respectively, while the $\mathrm{IC}_{50}$ values of standard antioxidants were $23.95,44.97,51.30,42.22$, and $52.72 \mathrm{mg} / \mathrm{mL}$, respectively [30]. 
<smiles>O=c1cc(-c2ccc(O)c(O)c2)oc2cc(O)cc(O)c12</smiles>

93<smiles>COc1ccc(-c2cc(=O)c3c(O)c(O)c(OC)c(OC)c3o2)cc1O</smiles>

100<smiles>O=c1cc(-c2ccc(O)cc2)oc2cc(O)cc(O)c12</smiles>

94<smiles></smiles>

$101 \mathrm{R} 1=\mathrm{OCH} 3, \mathrm{R} 2=\mathrm{OCH} 3, \mathrm{R} 3=\mathrm{H}$ $102 \mathrm{R} 1=\mathrm{OCH} 3, \mathrm{R} 2=\mathrm{H}, \mathrm{R} 3=\mathrm{OCH} 3$ $103 \mathrm{R} 1=\mathrm{OCH} 3, \mathrm{R} 2=\mathrm{OCH} 3, \mathrm{R} 3=\mathrm{OCH} 3$<smiles>COc1cc2oc(-c3ccc(O)cc3)cc(=O)c2c(O)c1OC</smiles>

106<smiles>O=c1c(O)c(-c2ccc(O)c(O)c2)oc2cc(O)cc(O)c12</smiles>

109<smiles>O=c1cc(-c2ccc(O)c(I)c2)oc2cc(O)cc(O)c12</smiles>

95: R1=OH, R2=-D-glucopyranosyl 96: $\mathrm{R} 1=\mathrm{OH}, \mathrm{R} 2=-\mathrm{D}$-glucuronyl

97: R1=OH, R2= $\square$-D-xylopyranosy

98: R1=H, R2=-D-glucuronyl

99: R1=H, R2=-D-glucuronyl methyl ester<smiles>O=c1cc(-c2ccc(O)cc2)oc2cc(O)c(O)cc12</smiles>

104<smiles>COc1cc(O)c2c(=O)cc(-c3ccc(O)cc3)oc2c1</smiles>

107<smiles>O=c1c(O)c(-c2ccc(O)cc2O)oc2cc(O)cc(O)c12</smiles>

110<smiles>COc1ccc(C2Oc3cc(O)cc(O)c3C(=O)C2O)cc1O</smiles>

113<smiles>COc1ccc([C@H]2CC(=O)c3c(O)cc(O[C@@H]4OC(COC5[C@@H](O)[C@H](O)[C@H](O)[C@H](O)[C@H]5O)C[C@H](C)[C@H]4O)cc3O2)cc1</smiles>

114<smiles>O=C1CC(c2ccc(O)cc2)Oc2cc(OC3OC(CO)C(O)C(O)C3COC3OC(O)[C@@H](O)[C@H](O)C3O)cc(O)c21</smiles>

112<smiles>C=C(C)CCc1c(O)cc(O)c2c1OC(c1ccc(OC)cc1)C(OC1OC(C)[C@@H](O)[C@H](O)[C@H]1OC1OC(CO)[C@@H](O)[C@H](O)C1O)C2=O</smiles>

115

FIGURE 4: Flavonoids of nonvolatile constituents isolated from genus Origanum in the world.

Yao et al. found that adding proper amount of OEO to the diet could increase the total antioxidant level in the serum of weaned piglets, increase the activity of GSH-PX and SOD, reduce the content of lipid peroxide MDA, and enhance the antioxidant performance of the body [31]. Botsoglou found that adding $200 \mathrm{mg} / \mathrm{kg}$ of O. vulgare essential oils into the diet of rabbits could effectively delay the oxidation of fat, and its antioxidant capacity is equivalent to $200 \mathrm{mg} / \mathrm{kg}$ of $\alpha$-tocopherol acetate [32]. Wang found that adding proper amount of OEO in rabbit feed could improve the activity of antioxidant enzymes in liver and serum [33]. Spiridon studied the antioxidant effect of essential oils in 
<smiles>Oc1ccc(O)cc1</smiles>

116<smiles>O=C(O)/C=C/c1ccccc1</smiles>

120<smiles>COc1cc(/C=C/C(=O)O)ccc1O</smiles>

124<smiles>O=C(O)c1ccc(O)c(O)c1</smiles>

128<smiles>Oc1ccccc1O</smiles>

117<smiles>O=C(O)/C=C/c1ccccc1O</smiles>

121<smiles>O=C(/C=C/c1ccc(O)c(O)c1)O[C@@H]1C[C@](O)(C(=O)O)C[C@H](O)[C@H]1O</smiles>

125<smiles>COc1cc(C(=O)O)ccc1O</smiles>

129<smiles>Oc1ccc(O)c(O)c1</smiles>

118<smiles>O=C(O)/C=C/c1ccc(O)cc1</smiles>

122<smiles>O=C(/C=C/c1ccc(O)c(O)c1)OC(Cc1ccc(O)c(O)c1)C(=O)O</smiles>

126

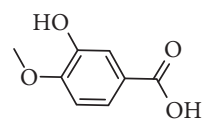

130<smiles>Cc1cc(O)c(O)cc1C(C)C</smiles>

119<smiles>O=C(O)/C=C/c1ccc(O)c(O)c1</smiles>

123<smiles>O=C(O)c1ccc(O)cc1</smiles>

127<smiles>COc1cc(C(=O)O)cc(OC)c1O</smiles>

131<smiles>O=C(O)CCC(=O)O</smiles>

FIgURE 5: Organic acids of nonvolatile constituents isolated from genus Origanum in the world.

vitro from $O$. vulgare and found that the addition of its essential oils to edible sesame oils could prevent the oxidation of grease and maintain the stability of grease which showed that it had a good antioxidant effect [34].

3.3. Anticancer Effect. Dhaheri demonstrated that $O$. majorana significantly inhibited the migration and invasion of the MDA-MB-231 cells by wound-healing assays. MMPs are known to play an important role in breast cancer cell invasion and metastasis. The protein level of MMP-2 and MMP-9 was found to be significantly reduced after O. majorana essential oils (OME) treated MDA-MB-231 cells. Meanwhile, O. majorana could decrease adhesion of MBAMB-231 to HUVEC, and the level of ICAM-1 protein decreased in concentration-dependent manner in OMEtreated MDA-MB-231 cells. In addition, the inhibitory effect of OME on the growth and metastasis of chicken blastoma further confirmed its antibreast cancer activity in vitro [35].
O. onites essential oils (OOEO) exhibited a dose-dependent antiproliferative activity against four types of human cancer cells: melanoma cells (A375), breast cancer cells (MCF-7), hepatocellular carcinoma cells (HepG2), and colon cancer cells (HT-29) lines with $\mathrm{IC}_{50}$ values of $8.90 \pm 0.70,10.0 \pm 1.7,23.0 \pm 4.2$ and $0.35 \pm 0.2 \mathrm{~g} / \mathrm{mL}$, respectively. Among the cell lines studied, colon cancer cells were the most sensitive to OOEO's antiproliferative activity. Moreover, when administered orally, OOEO inhibited the growth of colon carcinoma tumors in mice [3].

OEO could reduce cell density, slow cell growth, shrinking, fragmentation, and floating. MTT method was used to detect HepG2, human cervical cancer cell line (JTC26) and lung cancer cell line A549 treated with OEO. It was found that the cells treated with OEO show obvious inhibition of cell growth. Bliss method calculated that the $\mathrm{IC}_{50}$ values of OEO against hepatocellular carcinoma cells HepG2, human cervical cancer cell line JTC-26, and lung 
<smiles>C[C@H]1CC2(C(=O)O)CCC(C)(C)CC2C2=CCC3C(C)(CCC4[C@H](C)C(O)CCC43C)C21</smiles>

136<smiles>OCC1O[C@@H](Oc2ccc(O)cc2)[C@H](O)[C@@H](O)[C@@H]1O</smiles>

137

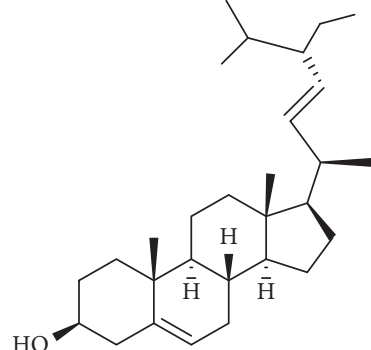

138

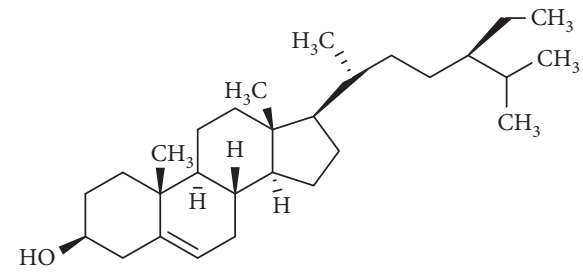

139<smiles>CCC(CCC(C)C1CCC2C3CC=C4CC(OC5O[C@@H](CO)[C@@H](O)[C@H](O)[C@H]5O)CCC4(C)C3CCC12C)C(C)C</smiles>

140

FIGURE 6: Steroids and terpenes of nonvolatile constituents isolated from genus Origanum in the world.

cancer A549 were $0.118,0.118$, and $0.059 \mathrm{mg} / \mathrm{mL}$, respectively [36].

Sankar reported the cytotoxic effects of green silver nanoparticles synthesized by reducing $1 \mathrm{mM}$ silver nitrate solution from $O$. vulgare water extract on human lung cancer A549 cells for the first time. Silver nanoparticles $(500 \mathrm{~g} / \mathrm{mL})$ significantly inhibited cell growth, and the inhibition rate was up to $85 \%$, which may be due to the presence of carvacrol, terpinenes, thymol, sabinene, linalool, terpinolene, quercetin, and apigenin in O. vulgare [37]. In addition, Jelnar found that in the essential oils of genus Origanum, there is a substance called trans-sabinene hydrate, which could play the role of antiproliferation of breast cancer cell line [38].

3.4. Anti-Inflammatory Effect. O. vulgare water extract intervenes with the RAW264.7 macrophage inflammatory model which was induced by LPS, TNF- $\alpha$, and MCP-1 (monocyte chemotactic protein 1). PGE2, NO, and IL- 6 were detected by ELISA. mRNA expression levels of TNF- $\alpha$, IL-6, and MPC-1 (CC chemokine ligand 2) were detected by q-PCR. O. vulgare water extract had a good inhibitory effect on LPS-induced RAW264.7 macrophage inflammation by the detection of ELISA and mRNA expression levels. It could reduce the production of cytokines such as PGE2, IL-6, TNF- $\alpha$, and MCP1 in cells, as well as the expression levels of IL- 6 , TNF- $\alpha$, and MCP-1 mRNA. These effects may be the mechanism of the anti-inflammatory activity of $O$. vulgare water extract [39].

Ocaña-Fuentes found that carvacrol and thymol from $O$. vulgare essential oils could reduce the synthesis of proinflammatory tumor necrosis factor, $\beta$-IL and synthesis of IL-6 cytokines, and increase the synthesis of anti-inflammatory IL-10. This indicated that some chemical components of $O$. vulgare essential oils have a strong antiinflammatory effect on human THP-1 cells [40].

The effects of iNOS protein and COX-2 expression of rosmarinic acid, ursolic acid, and oleanolic acid from Oregano were observed by Nitrite Assay and western blotting. The reduced expression of iNOS protein by these compounds was consistent with reductions on the nitrite production assay, and these three compounds also suppressed COX-2 protein expression on western blotting, showing comparable anti-inflammatory activities contrasting to indomethacin, a recognized COX-2 inhibitor [41].

In addition, it had been reported that the methanol extract of $O$. vulgare can inhibit the secretion of COX-2 and have antiinflammatory activity in human epithelial cancer cells. Methanol extract treatment specifically attenuated the proinflammatory response mediated by $\mathrm{T}$ helper 17 cells and enhanced anti-inflammatory $\mathrm{T}$ helper 2 and $\mathrm{T}$ regulatory cells through the impact on specific signalling pathways and transcription factors [42]. Yoshino et al. found that oregano extract exhibited anti-inflammatory activities in mouse models of stress-induced gastritis and contact hypersensitivity [43].

3.5. Immune Regulation. Both high and low doses of essential oils of $O$. vulgare had significant inhibitory effects on ear skin delayed hypersensitivity (DTH) induced by 2, 4dinitrochlorobenzene through foot pad reaction and ear swelling test of mice. The determination of serum hemolysin and the spectrophotometric determination of spleen cell- 
<smiles>COC(=O)[C@H]1Oc2cc(C(=O)CCc3ccc(OC4OC(CO)C(O)C(O)C4O)cc3)ccc2O[C@@H]1c1ccc(O)c(O)c1</smiles>

141<smiles>O=C(OCc1ccc(OC2O[C@H]3[C@H](O)[C@@H](O)[C@@H](O)[C@@H](O)[C@H]3O2)c(O)c1)c1ccc(O)c(O)c1</smiles>

$142 \mathrm{R}=\mathrm{H}$ $143 \mathrm{R}=\mathrm{Me}$<smiles>CCOC(=O)C(Cc1ccc(O)c(O)c1)OC(=O)/C=C/c1ccc(O)c(O)c1</smiles>

144<smiles>CCCCOC(=O)C(Cc1ccc(O)c(O)c1)OC(=O)/C=C/c1ccc(O)c(O)c1</smiles>

145

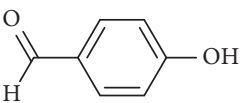

146<smiles>COc1cc([C@@H]2Oc3c(OC)cc(CCCO)cc3[C@@H]2CO)ccc1O</smiles>

147<smiles>CCOC(=O)/C=C/c1ccc(O)c(O)c1</smiles>

148

FIGURE 7: Other nonvolatile constituents isolated from the genus Origanum in the world.

mediated erythrocyte hemolysis showed that the high dose of essential oils could significantly inhibit the specific humoral immune function of mice. However, the low dose $(50 \mathrm{mg} / \mathrm{kg} / \mathrm{d} \times 7 \mathrm{~d})$ of essential oils had a very obvious promoting effect on the specific humoral immune function of mice. Moreover, the thymus and spleen of mice were significantly shrunk by a high dose of essential oils, but the spleen of mice was significantly enhanced by the low dose, which suggested that the essential oils of $O$. vulgare could affect the humoral and cellular immune function of mice [44].

Wang added OEO to broilers, and the results showed that at 42 days of age, the activity of acid $\alpha$-naphthyl acetate esterase in $\mathrm{T}$ lymphocyte and the $\mathrm{T}$ lymphocyte conversion rate in the $100 \mathrm{mg} / \mathrm{kg}$ OEO group increased by $16.56 \%$ and $13.90 \%$, respectively, compared with the control group $(P<0.05)$, which significantly enhanced the cellular immunity of broilers [45]. Malayoğlu added $500 \mathrm{mg} / \mathrm{kg}$ of $O$. vulgare essential oils to the diet of broilers and found a significant increase of IgG in the blood of broilers compared with the control group [46]. Hashemipour et al. indicated that long-term addition of carvacrol and thymol, the main components of OEO, could enhance cellular and humoral immunity of broilers [47].
3.6. Hypoglycemic Effect. O. vulgare leaves extract could inhibit gluconeogenesis, reduce lipid synthesis, and alleviate oxidative damage to reduce blood sugar. The $O$. vulgare extracts collected in October could effectively inhibit $\alpha$-glucosidase, promote glucose absorption, reduce glycosylation levels, alleviate the oxidative damage caused by the overexpression of cytochrome P4502E1 (CYP2E1) in E47 cells, repair the activity of lactate dehydrogenase (LDH) in damaged cells, and reduce oxidative stress level caused by oxygen free radicals (ROS). The mechanism may be related to the reduction of the promoter activity of phosphoenolpyruvate kinase (PEPCK), the key factor of gluconeogenesis in HepG2 cells, and the expression of its mRNA and protein. It decreased the promoter activity of cholesterol regulating protein element (SREBP-1c), a key factor in lipid synthesis, and the expression of its mRNA and protein. It could also inhibit the expression of CYP2E1 mRNA and protein in E47 cells and increase the expression of glucose transporter 2 (GLUT2) mRNA and protein. Therefore, phenols and flavonoids may be the main active components in O. vulgare [48].

The water extract and methanol extract of $O$ vulgare were used in C57BL/6 mice with multiple low-dose streptozotocin-induced diabetes, respectively. Water extract had no 
effect on the induction of diabetes. Methanol extract could reduce the incidence of diabetes and maintain normal insulin secretion. Methanol extract prevented apoptosis of $\beta$ cells by blocking caspase 3 in vitro, which may be relevant to rosmarinic acid, the dominant compound in methanol extract [42].

Vanadate was used as reference drug, and the hypoglycemic effect of $O$. vulgare was tested in normal and streptozotocin (STZ) induced diabetic rats. The results showed that $O$. vulgare leaves water extract had significant hypoglycemic effect on STZ diabetic rats. The low dose of O. vulgare water extract $(20 \mathrm{mg} / \mathrm{kg})$ for 2 weeks was enough to normalize blood glucose levels in severely diabetic rats with fasting blood glucose of more than $20 \mathrm{mM}$. Furthermore, O. vulgare leaves extract had no effect on basal plasma insulin concentration of normal and diabetic rats. This indicate that $O$. vulgare extract could inhibit glucose production in the liver, but not related to insulin secretion by islet cells [49].

3.7. Growth-Promoting Effect. The unique aroma of O. vulgare essential oils could stimulate the appetite of animals, stimulate the receptors of digestive tract, activate the activity of digestive enzymes, and promote the absorption of nutrients in the feed. The main chemical constituents of $O$. vulgare were thymol and carvol, which could enhance the barrier function of the intestinal tract and reduce the infection rate of pathogenic microorganisms to epithelial cells. In addition, the unique bactericidal and bacteriostatic effects of $O$. vulgare essential oils inhibit the growth of harmful bacteria in the intestinal tract of animals, maintain the balance of intestinal flora, and improve the absorption capacity of animals to nutrients, thereby improving the utilization rate of feed and ultimately promoting the growth of animals [13].

A comparative study on adding $\mathrm{OEO}$ and virginiamycin to chicken feed showed that the activity of intestinal protease in the group with the addition of OEO was $50 \%$ higher than that in the group with the addition of virginiamycin. The feed conversion rate of the OEO group was better than that of the virginiamycin group [50].

3.8. Liver Protection Effect. Ali found that O. vulgare leaf extract not only led to a significant decrease in serum ALT, AST, and ALP but also prevented liver damage [51].

3.9. Antispasmodic Effect. Different gastrointestinal smooth muscles were cultured to study the antispasmodic action of $O$. compactum in vitro. The results showed that aqueous extract of $O$. compactum powder could inhibit the effects of acetylcholine, histamine, serotonin, $\mathrm{BaCl}_{2}, 1,1$ dimethyl-4-phenylpiperazinium iodide, and nicotine responses to the guinea pig ileum and also block contractions elicited by electrical coaxial stimulation. Thymol and carvacrol were the active components of antispasmodic effect, which could block the release of intracellular bound
$\mathrm{Ca}^{2+}$ and prevent the extracellular $\mathrm{Ca}^{2+}$ influx into smooth muscle cells [52].

3.10. Insecticidal Effect. El-Akhal found O. majorana essential oils could kill Culex pipiens larvae with $\mathrm{LC}_{50}$ $258.71 \mathrm{mg} / \mathrm{L}$, which showed that O. majorana essential oils were an important natural insecticide [53].

Víctor tested the inhibitory activity of O. compactum essential oils to parasitic nematode Anisakis simplex and found that $O$. compactum essential oils showed a dosedependent larvicidal activity at 24 and $48 \mathrm{~h}$ after treatments. All larvae were killed at doses of $1 \mu \mathrm{L} / \mathrm{mL}$ after $24 \mathrm{~h}$. The effects of carvacrol and thymol on the larvae were similar to those of the oils. However, carvacrol exhibited a stronger activity than O. compactum and thymol, indicating that carvacrol might be responsible for the larvicidal effects [54].

3.11. Enzyme Inhibition. Goun discovered that aristolochia acid I and aristolochia acid II in O. vulgare could strongly inhibit thrombin activity [55]. Victor found O. compactum essential oils, carvacrol, and thymol had inhibitory effects on acetylcholinesterase [54]. The inhibitory activity of tyrosinase was detected by mushroom tyrosinase with arbutin as a positive control. The values for tyrosinase inhibitory activity of $O$. vulgare essential oils, ethanol extract, and arbutin were calculated to be $6.5 \pm 0.2 \%, 26.5 \pm 0.3 \%$, and $50.0 \pm 0.1 \%$, respectively. Both O. vulgare essential oils and ethanol extract had certain inhibitory effects on tyrosinase activity [56]. The pharmacological activities of Origanum plants are listed in Table 3.

\section{Summary and Prospects}

In summary, the essential oils of genus Origanum are the research focus and the components were mainly analyzed by GC-MS. The results showed that essential oils' compositions and content depend on the different parts of the plants and the origin of the plants. The main chemical components of essential oils are terpenoids and they have many pharmacological activities such as antibacterial, antioxidant, anticancer, anti-inflammatory, immune regulative, hypoglycemic, and growth promoting.

The essential oils of genus Origanum can be developed as a natural food additive because of its strong antibacterial and bactericidal effects. It also can be used as a natural growth promoter and insecticide. However, the anticancer and antioxidation studies of essential oils in Origanum plants are mainly conducted in vitro experiments. It can be further studied in vivo and the mechanism can be discussed. At present, the studies on the activities of Origanum plants are mainly focused on the extract of essential oil. In the future, the research can be transferred to the biological activity of monomer compounds of essential oil in Origanum plants.

In addition, the researches for nonvolatile constituents and their pharmacological activities are few. Therefore, the research on nonvolatile constituents of genus Origanum also 
TABle 3: Pharmacological activities of Origanum plants.

\begin{tabular}{|c|c|c|c|c|}
\hline $\begin{array}{l}\text { Type of the } \\
\text { activities }\end{array}$ & Subjects & Activities & Supplement & References \\
\hline \multirow{4}{*}{$\begin{array}{l}\text { Antibacterial } \\
\text { effect }\end{array}$} & $\begin{array}{l}\text { O. compactum essential } \\
\text { oils }\end{array}$ & $\begin{array}{c}\text { Against salmonella enteritis, } \\
\text { Salmonella typhimurium, Escherichia } \\
\text { coli, Listeria monocytogenes, } \\
\text { Staphylococcus epidermis, and } \\
\text { Staphylococcus aureus. } \\
\text { Against Escherichia coli, Bacillus } \\
\text { subtilis, Staphylococcus aureus, and } \\
\text { Listeria innocua. }\end{array}$ & $\begin{array}{l}\text { The inhibitory zone diameters of the } \\
\text { six colonies were } 25 \pm 0.5 \mathrm{~mm} \text {, } \\
20 \pm 0.7 \mathrm{~mm}, 30 \pm 1.0 \mathrm{~mm} \text {, } \\
25 \pm 0.5 \mathrm{~mm}, 25 \pm 0.5 \mathrm{~mm} \text {, } \\
34 \pm 0.5 \mathrm{~mm} \text {, respectively. } \\
\text { The minimum inhibitory } \\
\text { concentration (MIC: } 0.06-0.25 \% \text { (v/ } \\
\text { v)) and the minimum bactericidal } \\
\text { concentration (MBC: } 0.12-0.5 \%(\mathrm{v} / \\
\mathrm{v})) .\end{array}$ & {$[24]$} \\
\hline & $\begin{array}{l}\text { Methanol extract and } \\
\text { O. acutidens essential oils }\end{array}$ & $\begin{array}{l}\text { Obviously inhibit Staphylococcus } \\
\text { aureus, Lactococcus garvieae, Yersinia } \\
\text { ruckeri, and Aeromonas hydrophila. }\end{array}$ & $\begin{array}{l}\text { The mean inhibitory zones of } \\
\text { methanol extract and } O \text {. acutidens } \\
\text { essential oils on the bacterial strains } \\
\text { were } 28.0 \pm 1.2 \mathrm{~mm} \text { and } 36.7 \pm 0.7 \mathrm{~mm} \text {. }\end{array}$ & {$[25]$} \\
\hline & O. vulgare L. essential oils & Inhibit Staphylococcus aureus. & $\begin{array}{c}\text { When the concentration reached } 0.15 \\
\text { or } 0.3 \mu \mathrm{L} / \mathrm{mL} \text {, the growth of bacteria } \\
\text { was significantly inhibited. }\end{array}$ & {$[26]$} \\
\hline & OEO & $\begin{array}{l}\text { The antibacterial effects of OEO in } \\
\text { combination with fluoroquinolones, } \\
\text { doxycycline, lincomycin, and } \\
\text { maquindox florfenicol displayed } \\
\text { synergism against Escherichia coli. The } \\
\text { antibacterial effects of OEO combined } \\
\text { with amoxicillin, polymycin, and } \\
\text { lincomycin showed an additive effect } \\
\text { against Escherichia coli. }\end{array}$ & 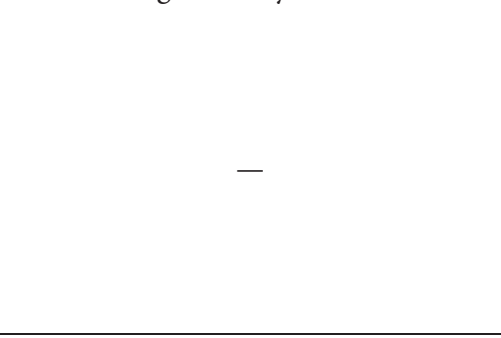 & [27] \\
\hline \multirow{6}{*}{$\begin{array}{l}\text { Antioxidant } \\
\text { effect }\end{array}$} & O. dubium extract & $\begin{array}{c}\text { Antioxidant activity, antilipid } \\
\text { peroxidation, and inhibitory activity } \\
\text { of lipoxygenase. }\end{array}$ & - & {$[28]$} \\
\hline & $\begin{array}{l}\text { O. vulgare L. subsp. } \\
\text { glandulosum (Desf.) } \\
\text { essential oils }\end{array}$ & Scavenge the DPPH radicals. & $\begin{array}{l}\text { The } \mathrm{IC}_{50} \text { values of three kinds of } \\
\text { essential oils ranged from } 59 \text { to } 80 \mathrm{mg} / \\
\text { L. }\end{array}$ & [29] \\
\hline & O. majorana essential oils & $\begin{array}{l}\text { Exhibited concentration-dependent } \\
\text { inhibitory effects on DPPH, hydroxyl } \\
\text { radical, hydrogen peroxide, reducing } \\
\text { power, and lipid peroxidation. }\end{array}$ & $\begin{array}{c}\mathrm{IC}_{50} \text { values of } 58.67,67.11,91.25 \\
78.67 \text {, and } 68.75 \mathrm{mg} / \mathrm{mL} \text {, respectively. }\end{array}$ & {$[30]$} \\
\hline & O. vulgare L. essential oils & $\begin{array}{l}\text { Increase the total antioxidant level in } \\
\text { the serum of weaned piglets, increase } \\
\text { the activity of GSH-PX and SOD, } \\
\text { reduce the content of lipid peroxide } \\
\text { MDA, and enhance the antioxidant } \\
\text { performance of the body. }\end{array}$ & - & {$[31]$} \\
\hline & OEO & Effectively delay the oxidation of fat. & $\begin{array}{l}\text { Adding } 200 \mathrm{mg} / \mathrm{kg} \text { of } O . \text { vulgare } \\
\text { L. essential oils into the diet of rabbits. }\end{array}$ & {$[32]$} \\
\hline & O. vulgare essential oils & $\begin{array}{l}\text { Improve the activity of antioxidant } \\
\text { enzymes in liver and serum of rabbit. } \\
\text { The addition of its essential oils to } \\
\text { edible sesame oils could prevent the } \\
\text { oxidation of grease and maintain the } \\
\text { stability of grease. }\end{array}$ & - & {$[34]$} \\
\hline
\end{tabular}


TABle 3: Continued.

\begin{tabular}{|c|c|c|c|c|}
\hline $\begin{array}{l}\text { Type of the } \\
\text { activities }\end{array}$ & Subjects & Activities & Supplement & References \\
\hline \multirow{5}{*}{$\begin{array}{l}\text { Anti-cancer } \\
\text { effect }\end{array}$} & O. majorana essential oils & $\begin{array}{c}\text { Significantly inhibited the migration } \\
\text { and invasion of the MDA-MB-231 } \\
\text { cells. }\end{array}$ & $\begin{array}{l}\text { Suppress the phosphorylation of } \mathrm{I} \kappa \mathrm{B} \text {, } \\
\text { downregulate the nuclear level of } \\
\mathrm{NF} \kappa \mathrm{B} \text {, and reduce nitric oxide (NO) } \\
\text { production in MDA-MB-231 cells. }\end{array}$ & [35] \\
\hline & $\begin{array}{l}\text { O. onites essential oils } \\
\text { (OOEO) }\end{array}$ & $\begin{array}{l}\text { Exhibit a dose-dependent } \\
\text { antiproliferative activity against four } \\
\text { types of human cancer cells: } \\
\text { melanoma cells (A375), breast cancer } \\
\text { cells (MCF-7), hepatocellular } \\
\text { carcinoma cells (HepG2), and colon } \\
\text { cancer cells (HT-29) lines. }\end{array}$ & $\begin{array}{l}\text { The antiproliferative effect (lowest } \\
\left.\text { IC }_{50} \text { value for } 72 \mathrm{~h}\right) \text { was observed in } \\
\text { the HT- } 29(0.35 \pm 0.2 \mu \mathrm{g} / \mathrm{mL}) \text { followed } \\
\text { by A375 }(8.90 \pm 0.7 \mu \mathrm{g} / \mathrm{mL}) \text {, MCF-7 } \\
(10.0 \pm 1.7 \mu \mathrm{g} / \mathrm{mL}) \text {, and HepG } 2 \\
(23.0 \pm 4.2 \mu \mathrm{g} / \mathrm{mL}) \text {. }\end{array}$ & {$[3]$} \\
\hline & $\mathrm{OEO}$ & $\begin{array}{l}\text { Inhibit liver cancer HepG2, son of } \\
\text { man cervical cancer JTC-26, and lung } \\
\text { cancer A549 growth. }\end{array}$ & 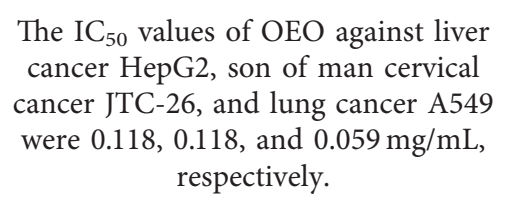 & {$[36]$} \\
\hline & O. vulgare water extract & $\begin{array}{l}\text { Green silver nanoparticles synthesized } \\
\text { by reducing } 1 \mathrm{mM} \text { silver nitrate } \\
\text { solution from O. vulgare water extract } \\
(500 \mathrm{~g} / \mathrm{mL}) \text { significantly inhibited } \\
\text { human lung cancer A } 549 \text { cells growth. }\end{array}$ & $\begin{array}{c}\text { The green synthesized silver } \\
\text { nanoparticles against human lung } \\
\text { cancer A549 cell line (LD 50-100 } \mathrm{g} / \\
\mathrm{ml} \text { ). }\end{array}$ & {$[37]$} \\
\hline & $\begin{array}{l}\text { Trans-sabinene hydrate } \\
\text { from genus Origanum } \\
\text { essential oils }\end{array}$ & $\begin{array}{c}\text { Antiproliferation of breast cancer cell } \\
\text { line. }\end{array}$ & - & {$[38]$} \\
\hline \multirow{5}{*}{$\begin{array}{l}\text { Anti- } \\
\text { inflammatory } \\
\text { effect }\end{array}$} & O. vulgare L. water extract & $\begin{array}{c}\text { Have a good inhibitory effect on LPS- } \\
\text { induced RAW264.7 macrophage } \\
\text { inflammatory. }\end{array}$ & $\begin{array}{l}\text { Reduce the production of cytokines } \\
\text { such as PGE2, IL-6, TNF- } \alpha \text {, and MCP- } \\
1 \text { in cells, as well as the expression } \\
\text { levels of IL-6, TNF- } \alpha \text {, and MCP-1 } \\
\text { mRNA. }\end{array}$ & {$[39]$} \\
\hline & O. vulgare essential oils & $\begin{array}{l}\text { O. vulgare essential oils have a strong } \\
\text { anti-inflammatory effect on human } \\
\text { THP-1 cells. }\end{array}$ & $\begin{array}{l}\text { Carvacrol and thymol from } O \text {. vulgare } \\
\text { essential oils could reduce the } \\
\text { synthesis of proinflammatory tumor } \\
\text { necrosis factor, } \beta \text {-IL, and synthesis of } \\
\text { IL- } 6 \text { cytokines and increase the } \\
\text { synthesis of anti-inflammatory IL-10. }\end{array}$ & {$[40]$} \\
\hline & $\begin{array}{l}\text { Rosmarinic acid, ursolic } \\
\text { acid, and oleanolic acid } \\
\text { from oregano }\end{array}$ & $\begin{array}{c}\text { Exhibit comparable anti- } \\
\text { inflammatory activities contrasting to } \\
\text { indomethacin, a recognized COX-2 } \\
\text { inhibitor. }\end{array}$ & $\begin{array}{c}\text { Reduce expression of iNOS protein } \\
\text { and suppress COX-2 protein } \\
\text { expression. }\end{array}$ & {$[41]$} \\
\hline & $\begin{array}{c}\text { The methanol extract of } \\
\text { O. vulgare }\end{array}$ & $\begin{array}{l}\text { Inhibit the secretion of COX-2 and } \\
\text { had anti-inflammatory activity in } \\
\text { human epithelial cancer cells. }\end{array}$ & $\begin{array}{l}\text { Methanol extract specifically } \\
\text { attenuated the proinflammatory } \\
\text { response mediated by T helper } 17 \text { cells } \\
\text { and enhanced anti-inflammatory T } \\
\text { helper } 2 \text { and T regulatory cells. }\end{array}$ & {$[42]$} \\
\hline & Oregano extract & $\begin{array}{l}\text { Exhibit anti-inflammatory activities in } \\
\text { mouse models of stress-induced } \\
\text { gastritis and contact hypersensitivity. }\end{array}$ & - & {$[43]$} \\
\hline
\end{tabular}


TABle 3: Continued.

\begin{tabular}{|c|c|c|c|c|}
\hline $\begin{array}{l}\text { Type of the } \\
\text { activities }\end{array}$ & Subjects & Activities & Supplement & References \\
\hline $\begin{array}{l}\text { Immune } \\
\text { regulation }\end{array}$ & O. vulgare L. essential oils & $\begin{array}{l}\text { Both the high dose of } 100 \mathrm{mg} / \mathrm{kg} / \\
\mathrm{d} \times 7 \mathrm{~d} \text { and the low dose of } 50 \mathrm{mg} / \mathrm{kg} / \\
\mathrm{d} \times 7 \mathrm{~d} \text { had obvious inhibitory effect } \\
\text { on the specific cellular immune } \\
\text { function of normal mice. The dose of } \\
50 \mathrm{mg} / \mathrm{kg} / \mathrm{d} \times 7 \mathrm{~d} \text { significantly } \\
\text { promoted the humoral immunity of } \\
\text { mice, and } 100 \mathrm{mg} / \mathrm{kg} / \mathrm{d} \times 7 \mathrm{~d} \\
\text { significantly inhibited the humoral } \\
\text { immunity of mice. } \\
\text { Carvacrol and thymol of OEO could } \\
\text { enhance cellular and humoral } \\
\text { immunity of broilers. }\end{array}$ & - & {$[45]$} \\
\hline \multirow{3}{*}{$\begin{array}{l}\text { Hypoglycemic } \\
\text { effect }\end{array}$} & O. vulgare leaves extract & Significant hypoglycemic activity. & $\begin{array}{l}\text { By inhibiting } \alpha \text {-glucosidase activity, } \\
\text { promoting glucose uptake, and } \\
\text { inhibiting glycation. }\end{array}$ & [48] \\
\hline & $\begin{array}{c}\text { Methanol extract of } \\
\text { O. vulgare }\end{array}$ & $\begin{array}{l}\text { Methanol extract could reduce the } \\
\text { incidence of diabetes and maintain } \\
\text { normal insulin secretion. }\end{array}$ & $\begin{array}{l}\text { Methanol extract prevented apoptosis } \\
\text { of } \beta \text { cells in vitro by blocking caspase } 3 \text {. }\end{array}$ & {$[42]$} \\
\hline & $\begin{array}{c}\text { O. vulgare leaves water } \\
\text { extract }\end{array}$ & $\begin{array}{l}\text { O. vulgare leaves water extract had } \\
\text { significant hypoglycemic effect on } \\
\text { STZ diabetic rats. }\end{array}$ & $\begin{array}{l}\text { The low dose of } O \text {. vulgare water } \\
\text { extract }(20 \mathrm{mg} / \mathrm{kg}) \text { for } 2 \text { weeks was } \\
\text { enough to normalize blood glucose } \\
\text { levels in severely diabetic rats with } \\
\text { fasting blood glucose of more than } \\
20 \mathrm{mM} \text {. }\end{array}$ & [49] \\
\hline $\begin{array}{l}\text { Growth- } \\
\text { promoting effect }\end{array}$ & O. vulgare L. essential oils & $\begin{array}{l}\text { Stimulate the appetite of animals, } \\
\text { maintain the balance of intestinal } \\
\text { flora, and improve the absorption } \\
\text { capacity of animals to nutrients, } \\
\text { promoting the growth of animals. } \\
\text { Improve feed conversion rate. }\end{array}$ & - & [13] \\
\hline $\begin{array}{l}\text { Liver protection } \\
\text { effect }\end{array}$ & $\begin{array}{l}\text { Ethanol extract of } \\
\text { O. vulgare leaves }\end{array}$ & $\begin{array}{l}\text { The concentration of ethanol extract } \\
\text { of } O \text {. vulgare leaves below } 500 \mathrm{mg} / \mathrm{kg} \\
\text { had protective effect on paraquat- } \\
\text { induced hepatotoxicity in rats. }\end{array}$ & - & {$[51]$} \\
\hline
\end{tabular}
induced hepatotoxicity in rats.

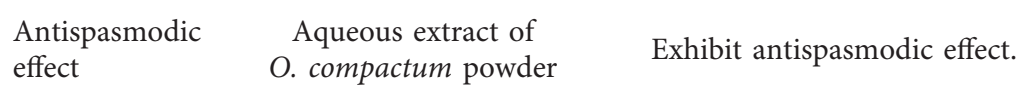

Aqueous extract of $O$. compactum powder inhibited the effects of acetylcholine, histamine, serotonin, $\mathrm{BaCl}_{2}, 1,1$-dimethyl-4-

phenylpiperazinium iodide, and nicotine responses on the guinea pig ileum and also blocked the contractions elicited by electrical coaxial stimulation.

The $\mathrm{LC}_{50}$ and $\mathrm{LC}_{90}$ are $258.71 \mathrm{mg} / \mathrm{L}$

(lower limit-upper limit:

The essential oil from the leaves of O. majorana

Insecticidal effect

O. compactum essential oils
Exhibit significant Culex pipienslarvicidal activity.

Larvicidal activity of $O$. compactum essential oil against Anisakis simplex L3 larvae.
$126.99-527.06 \mathrm{mg} / \mathrm{L}$ ) and $580.49 \mathrm{mg} / \mathrm{L}$ and $580.49 \mathrm{mg} / \mathrm{L}$ (lower limit-upper limit:354.51-950.53 mg/L), respectively.

$\mathrm{LD}_{50} 0.429 \mathrm{mg} / \mathrm{ml}$ at $24 \mathrm{~h}$ and $0.344 \mathrm{mg} / \mathrm{ml}$ at $48 \mathrm{~h}$. The mortality (\%) after 24 and $48 \mathrm{~h}$ of treatment at $1 \mu \mathrm{l} /$ $\mathrm{ml}$ was $100 \%$. 
TABLE 3: Continued.

\begin{tabular}{|c|c|c|c|c|}
\hline $\begin{array}{l}\text { Type of the } \\
\text { activities }\end{array}$ & Subjects & Activities & Supplement & References \\
\hline \multirow{4}{*}{$\begin{array}{l}\text { Enzyme } \\
\text { inhibition }\end{array}$} & $\begin{array}{l}\text { Aristolochia acid I and } \\
\text { aristolochia acid II } \\
\text { extracted from O. vulgare }\end{array}$ & Inhibit thrombin activity. & - & {$[55]$} \\
\hline & O. compactum essential & & O. compactum essential oils $\left(\mathrm{IC}_{50}\right.$ & \\
\hline & $\begin{array}{l}\text { oils, carvacrol and thymol } \\
\text { from O. compactum } \\
\text { essential oils }\end{array}$ & Inhibit acetylcholinesterase activity. & $\begin{array}{c}0.124 \mathrm{mg} / \mathrm{ml}) \text {, carvacrol }\left(\mathrm{IC}_{50}\right. \\
0.113 \mathrm{mg} / \mathrm{ml}) \text {, and thymol }\left(\mathrm{IC}_{50}\right. \\
0.625 \mathrm{mg} / \mathrm{ml})\end{array}$ & {$[54]$} \\
\hline & $\begin{array}{l}\text { O. vulgare essential oils, } \\
\text { ethanol extract }\end{array}$ & Inhibit tyrosinase activity. & $\begin{array}{l}\text { The values for tyrosinase inhibitory } \\
\text { activity of } O \text {. vulgare ethanol extract, } \\
\text { essential oil, and arbutin (positive } \\
\text { control) were calculated to be } \\
6.5 \pm 0.2 \%, 26.5 \pm 0.3 \% \text { and } \\
50.0 \pm 0.1 \% \text {, respectively. }\end{array}$ & {$[56]$} \\
\hline
\end{tabular}

can be strengthened and its application prospect can be explored so as to make better use of the resources of this plant.

\section{Conflicts of Interest}

All authors declare that they have no conflicts of interest.

\section{Authors' Contributions}

Li Zhou and Fatma Al-Zahra K. K. Attia performed literature collection and writing and original draft preparation. Lijun Meng and Sitan Chen analyzed and summarized data. Wenyi Kang and Zhenhua Liu critically reviewed the manuscript. Zhenhua Liu, Changyang Ma, and Lijun Liu supervised project administration. Wenyi Kang provided resources, funding, and reviewed the manuscript. All the authors contributed to the article and approved the submitted version.

\section{Acknowledgments}

This work was supported by the Key Project in Science and Technology Agency of Henan Province (192102110214 and 202102110149) and Precision Nutrition and Health Food, Department of Science and Technology of Henan Province (CXJD2021006).

\section{References}

[1] J. J. Li and R. T. Li, "Research status of Origanum vulgare L," Chinese Journal of Spectroscopy Laboratory, vol. 30, no. 1, pp. 171-176, 2013.

[2] H. Y. Gong, W. H. Liu, G. Y. Lv, and X. Zhou, "Analysis of essential oils of Origanum vulgare from six production areas of China and Pakistan," Revista Brasileira de Farmacognosia, vol. 24, no. 1, pp. 25-32, 2014.

[3] K. Spyridopoulou, E. Fitsiou, E. Bouloukosta, A. Tiptiri, and K. Chlichlia, "Extraction, chemical composition, and anticancer potential of Origanum onites L. essential oils," Molecules, vol. 24, no. 14, 2019.

[4] A. Ayhan, T. Nurhayat, T. Erno et al., "Characterization of volatile constituents from Origanum onites and their antifungal and antibacterial activity," Journal of AOAC International, vol. 96, no. 6, pp. 1200-1208, 2013.

[5] N. Aligiannis, E. Kalpoutzakis, S. Mitaku, and I. B. Chinou, "Composition and antimicrobial activity of the essential oils of two Origanum species," Journal of Agricultural and Food Chemistry, vol. 49, no. 9, pp. 4168-4170, 2001.

[6] A. Shafaghat, "Antibacterial activity and GC/MS analysis of the essential oils from flower, leaf and stem of Origanum vulgare ssp. viride growing wild in North-west Iran," Natural Product Communications, vol. 6, no. 9, pp. 1351-1352, 2011.

[7] M. Farhat, J. Tóth, B. É. Héthelyi, S. Szarka, and S. Czigle, "Analysis of the essential oil compounds of origanum syriacum L," Acta Facultatis Pharmaceuticae Universitatis Comenianae, vol. 59, no. 2, pp. 6-14, 2012.

[8] T. D. Pepa, H. S. Elshafie, R. Capasso et al., "Antimicrobial and phytotoxic activity of Origanum heracleoticum and O. majorana essential oils growing in cilento (Southern Italy)," Molecules, vol. 24, no. 14, 2019.

[9] Y.-L. Lin, C.-N. Wang, Y.-J. Shiao, T.-Y. Liu, and W.-Y. Wang, "Benzolignanoid and polyphenols from Origanum vulgare," Journal of the Chinese Chemical Society, vol. 50, no. 5, pp. 1079-1083, 2003.

[10] R. Erenler, O. Sen, H. Aksit et al., "Isolation and identification of chemical constituents from Origanum majorana and investigation of antiproliferative and antioxidant activities," Journal of the Science of Food and Agriculture, vol. 96, no. 3, pp. 822-836, 2016.

[11] H. B. Hu, "Studies on chemical constituents and bacteriostatic activities of Origanum vulgare Linn," Master's Thesis, Northwest Normal University, Lanzhou, China, 2005.

[12] Y. S. Guo, G. C. Wang, C. H. Wang, X. J. Huang, Y. L. Li, and W. C. Ye, "Chemical constituents of Origanum vulgare," Chinese Pharmaceutical Journal, vol. 47, no. 14, pp. 11091113, 2012.

[13] R. Wu, Q. Ye, N. Y. Chen, and G. Zhang, "Study on the chemical constituents of Origanum vulgare L," Natural Product Research and Development, vol. 6, pp. 13-16, 2000.

[14] J. F. Zan, "The pharmaceutical researcher on the kuanxin soft capsule," Master's Thesis, Hubei College of Chinese Medicine, Wuhan, China, 2005.

[15] L. J. Sun, H. B. Liu, W. Q. Fan, H. L. Xu, and Y. W. Liu, "Chemical constituents of Origanum vulgare (I)," Chinese herbal medicine, vol. 12, pp. 1782-1785, 2007.

[16] G. Liu, X. Meng, and N. Chen, "Study on the chemical constituents of Origanum vulgare," Journal of Chinese Medicinal Materials, vol. 9, pp. 640-641, 2002. 
[17] G. Rao, T. Mukhopadhyay, T. Annamalai, N. Radhakrishnan, and M. Sahoo, "Chemical constituents and biological studies of Origanum vulgare linn," Pharmacognosy Research, vol. 3, no. 2, pp. 143-145, 2011.

[18] B. Zhu, X. W. Cheng, and Y. X. Liu, "Advances in the chemical constituents, pharmacological activities and extraction methods of Origanum," Journal of Chinese Medicinal Materials, vol. 8, pp. 1038-1041, 2007.

[19] M. Hatipi, V. Papajani, S. Cavar, and R. Koliqi, "Analysis of volatile compounds of Origanum vulgare L. growing wild in kosovo," Journal of Essential Oil Bearing Plants, vol. 17, no. 1, pp. 148-157, 2014.

[20] W. Z. Huo, S. J. Wei, X. J. Yuan, X. B. Suo, and X. Y. Li, "Analysis of constituents in volatile oil from herba artemisiae capillariae and origanum vulgare L. by GC-MS," Journal of Guangdong Pharmaceutical College, vol. 26, no. 5, pp. 492496, 2010.

[21] L. L. Liu and K. X. Tian, "Study and application of oil origanum," Feed review, vol. 7, pp. 9-11, 2005.

[22] R. Dai, Y. Y. Ma, L. X. Gao, Y. T. Gao, and Z. L. Gu, "Working mechanism and appication of Origanum vulgare oil," Feed China, vol. 8, pp. 44-47, 2016.

[23] G. Mitropoulou, E. Fitsiou, E. Stavropoulou et al., "Composition, antimicrobial, antioxidant, and antiproliferative activity of Origanum dictamnus (dittany) essential oils," Microbial Ecology in Health and Disease, vol. 26, no. 1, 2015.

[24] Y. Laghmouchi, O. Belmehdi, N. S. Senhaji, and J. Abrini, "Chemical composition and antibacterial activity of Origanum compactum Benth. essential oils from different areas at northern Morocco," South African Journal of Botany, vol. 115, pp. 120-125, 2018.

[25] A. K. Gulec, P. Erecevit, E. Yuce, A. Arslan, E. Bagci, and S. Kirbag, "Antimicrobial activity of the methanol extracts and essential oil with the composition of endemic Origanum acutidens (lamiaceae)," Journal of Essential Oil Bearing Plants, vol. 17, no. 2, pp. 353-358, 2014.

[26] D. S. E. Leite, D. B. J. Carneiro, D. O. C. E. Vasconcelos, and D. C. M. Lúcia, "Influence of Origanum vulgare L. essential oils on enterotoxin production, membrane permeability and surface characteristics of Staphylococcus aureus," International Journal of Food Microbiology, vol. 137, no. 2-3, pp. 308-311, 2010.

[27] H. B. Si, J. Q. Hu, Z. C. Liu, and Z. L. Zeng, "Antibacterial effect of oregano essential oils alone and in combination with antibiotics against extended-spectrum beta-lactamase-producing Escherichia coli," FEMS Immunology and Medical Microbiology, vol. 53, no. 2, 2008.

[28] A. Karioti, T. Milošević-Ifantis, N. Pachopos, N. Niryiannaki, D. Hadjipavlou-Litina, and H. Skaltsa, "Antioxidant, antiinflammatory potential and chemical constituents of Origanum dubium Boiss. growing wild in Cyprus," Journal of Enzyme Inhibition and Medicinal Chemistry, vol. 30, no. 1, pp. 38-43, 2015.

[29] K. Mechergui, J. A. Coelho, M. C. Serra, S. B. Lamine, S. Boukhchina, and M. L. Khouja, "Essential oils of Origanum vulgare L. subsp. glandulosum (Desf.) ietswaart from Tunisia: chemical composition and antioxidant activity," Journal of the Science of Food and Agriculture, vol. 90, no. 10, pp. 1745-1749, 2010.

[30] A. T. H. Mossa and G. Nawwar, "Free radical scavenging and antiacetylcholinesterase activities of Origanum majorana L. essential oil," Human \& Experimental Toxicology, vol. 30, no. 10, pp. 1501-1513, 2011.
[31] J. Yao, H. X. Xu, and W. Q. Xu, "The effect of Origanum vulgare on the growth performance and serum oxidationantioxidation function of weaned piglets," Feed China, vol. 3, pp. 49-51, 2017.

[32] N. A. Botsoglou, P. Florou-Paneri, E. Christaki, I. Giannenas, and A. B. Spais, "Performance of rabbits and oxidative stability of muscle tissues as affected by dietary supplementation with Oregano essential oil," Archives of Animal Nutrition, vol. 58, no. 3, pp. 209-218, 2004.

[33] D. D. Wang, X. D. Dai, H. L. Ren, Z. Q. Wu, and Y. F. Lü, "Effect of dietary supplementation with origanum oil on growth performance,antioxidant indexes of meat rabbit," Feed Industry, vol. 34, no. 1, pp. 53-55, 2013.

[34] S. Kintzios, K. Papageorgiou, I. Yiakoumettis, D. Baričevič, and A. Kušar, "Evaluation of the antioxidants activities of four Slovene medicinal plant species by traditional and novel biosensory assays," Journal of Pharmaceutical and Biomedical Analysis, vol. 53, no. 3, pp. 773-776, 2010.

[35] Y. A. Dhaheri, S. Attoub, K. Arafat, A. Q. Synan, and V. Jean, "Anti-metastatic and anti-tumor growth effects of Origanum majorana on highly metastatic human breast cancer cells: inhibition of $\mathrm{NF} \kappa \mathrm{B}$ signaling and reduction of nitric oxide production," PLoS One, vol. 8, no. 7, 2013.

[36] Y. Wang, L. Wang, L. Li, J. X. Lu, S. X. Ma, and G. Chen, "Anti-tumor activity of Origanum oil in vitro," Chinese Journal of Microecology, vol. 22, no. 12, pp. 1101-1102, 2010.

[37] R. Sankar, A. Karthik, A. Prabu, S. Karthik, K. S. Shivashangari, and V. Ravikumar, "Origanum vulgare mediated biosynthesis of silver nanoparticles for its antibacterial and anticancer activity," Colloids and Surfaces B: Biointerfaces, vol. 108, pp. 80-84, 2013.

[38] J. Z. Al-Kalaldeh, R. Abu-Dahab, and F. U. Afifi, "Volatile oils composition and antiproliferative activity of Laurus nobilis, Origanum syriacum, Origanum vulgare, and Salvia triloba against human breast adenocarcinoma cells," Nutrition Research, vol. 30, no. 4, pp. 271-278, 2010.

[39] Z. Ismayil, "Study on antioxidation and anti-inflammatory effect of Origanum vulgare L." Master's Thesis, Xinjiang Medical University, Urumqi, China, 2018.

[40] A. Ocaña-Fuentes, E. Arranz-Gutiérrez, F. J. Señorans, and G. Reglero, "Supercritical fluid extraction of oregano (Origanum vulgare) essentials oils: anti-inflammatory properties based on cytokine response on THP-1 macrophages," Food and Chemical Toxicology, vol. 48, no. 6, pp. 1568-1575, 2010.

[41] D. Shen, M.-H. Pan, Q.-L. Wu, C. H. Park, and H. R. Juliani, "LC-MS method for the simultaneous quantitation of the antiinflammatory constituents in oregano (origanum species)," Journal of Agricultural and Food Chemistry, vol. 58, no. 12, pp. 7119-7125, 2010.

[42] V. Milica, N. Ivana, K. Vassiliki G, T. Saksida, and P. Charisiadis, "Methanolic extract of Origanum vulgare ameliorates type 1 diabetes through antioxidant, anti-inflammatory and anti-apoptotic activity," British Journal of Nutrition, vol. 113, no. 5, pp. 770-782, 2015.

[43] K. Yoshino, N. Higashi, and K. Koga, "Antioxidant and antiinflammatory activities of oregano extract," Journal of Health Science, vol. 52, no. 2, pp. 169-173, 2006.

[44] Q. H. Lin, C. F. Zhang, and Y. W. Liu, "Effects of volatile oil of Origanum vulgare L. on specific immunological functions in mice," Chinese Journal of Applied and Environmental Biology, vol. 3, no. 4, pp. 389-391, 1996.

[45] Q. M. Wang, "The effect of volatile oil of origanum vulgare L. on the growth performance and cellular immune function 
of broiler chicken," Animal husbandry and feed science, vol. 29, no. 3, pp. 13-16, 2008.

[46] H. B. Malayoğlu, S. Baysal, Z. Misirlioğlu, M. Polat, H. Yilmaz, and N. Turan, "Effects of O. vulgare L. essential oils with or without feed enzymes on growth performance, digestive enzyme, nutrient digestibility, lipid metabolism and immune response of broilsers fed on wheat-soybean meal diets," British Poultry Science, vol. 51, no. 1, pp. 67-80, 2010.

[47] H. Hashemipour, H. Kermanshahi, A. Golian, and T. Veldkamp, "Effect of thymol and carvacrol feed supplementation on performance, antioxidant enzyme activities, fatty acid composition, digestive enzyme activities, and immune response in broiler chickens," Poultry Science, vol. 92, no. 8, pp. 2059-2069, 2013.

[48] P. P. Zhang, Research on Hypoglycemic Activity and Mechanism of Origanum Vulgare L.Leaf Extract, Hubei University, Wuhan, China, 2018.

[49] A. Lemhadri, N. A. Zeggwagh, M. Maghrani, H. Jouad, and M. Eddouks, "Anti-hyperglycaemic activity of the aqueous extract of Origanum vulgare growing wild in Tafilalet region," Journal of Ethnopharmacology, vol. 92, no. 2-3, pp. 251-256, 2004.

[50] Y. M. Guo, J. L. Ding, Y. Q. Zhu, and Y. P. Xun, "The study on the effect of "Sudafei-500" on the growth performance of broiler chicken," China Feed, vol. 5, pp. 16-17, 1994.

[51] S.-R. Ali, H. Esfandiar, and A. S. Asadollah, "Protective and anti-inflammatory effects of hydroalcoholic leaf extract of Origanum vulgare on oxidative stress, TNF- $\alpha$ gene expression and liver histological changes in paraquat-induced hepatotoxicity in rats," Archives Internationales de Physiologie, vol. 125, no. 1, pp. 56-63, 2018.

[52] C. van den Broucke and J. Lemli, "Antispasmodic activity of Origanum compactum," Planta Medica, vol. 38, no. 4, pp. 317-331, 1980.

[53] F. El-Akhal, A. E. O. Lalami, Y. E. Zoubi, H. Greche, and R. Guemmouh, "Chemical composition and larvicidal activity of essential oil of Origanum majorana (Lamiaceae) cultivated in Morocco against Culex pipiens (Diptera: Culicidae)," Asian Pacific Journal of Tropical Biomedicine, vol. 4, no. 9, pp. 746-750, 2014.

[54] V. López, M. Cascella, G. Benelli, F. Maggi, and C. GómezRincón, "Green drugs in the fight against anisakis simplexlarvicidal activity and acetylcholinesterase inhibition of Origanum compactum essential oil," Parasitology Research, vol. 117, no. 3, pp. 861-867, 2018.

[55] E. Goun, G. Cunningham, S. Solodnikov, O. Krasnykch, and H. Miles, "Antithrombin activity of some constituents from Origanum vulgare," Fitoterapia, vol. 73, no. 7-8, pp. 692-694, 2002.

[56] A. Moghrovyan, N. Sahakyan, A. Babayan, N. Chichoyan, M. Petrosyan, and A. Trchounian, "Essential oil and ethanol extract of oregano (origanum vulgare L.) from Armenian flora as a natural source of terpenes, flavonoids and other phytochemicals with antiradical, antioxidant, metal chelating, tyrosinase inhibitory and antibacterial activity," Current Pharmaceutical Design, vol. 25, no. 16, pp. 1809-1816, 2019. 